\title{
O SUJEITO-GRUPO TRANS COMO FICÇÃO ESTÉTICO-POLÍTICA VIVA: DA LÓGICA DA IDENTIDADE À RELACIONALIDADE E À POLITICIDADE FUNDANTES
}

\author{
[THE TRANSGENDER SUBJECT-GROUP AS LIVING AESTHETICAL-POLITICAL FICTION: FROM THE \\ LOGIC OF IDENTITY TO THE FOUNDING RELATIONALITY AND POLITICITY]
}

\author{
Leno Francisco Danner * \\ Universidade Federal de Rondônia, Brasil
}

\begin{abstract}
Resumo: Refletiremos no texto sobre a ideia do sujeito-grupo trans como fiç̧ão estéticopolítica viva que se assume como perspectiva antifascista e antitotalitária a partir do enfrentamento da lógica da identidade prépolítica, pré-cultural e a-histórica que embasa a compreensão fascista-colonialista-racistaheteronormativa de sociedade-cultura-
\end{abstract} antropologia, afirmando, por meio da vozpráxis trans em sua cruzada antifascista e antitotalitária, a relacionalidade e a politicidade fundantes dessa mesma sociedade-culturaantropologia. Nesse sentido, desenvolveremos alguns argumentos básicos, caudatários dessa dinâmica própria ao pensamento-práxis trans: (a) as minorias político-culturais - o/a trans, o gay, o/a negro/a, o/a índio/a, a mulher - são construções sociais, historicamente localizadas e politicamente realizadas, não tendo uma constituição pré-política, pré-cultural e ahistórica; (b) eles são caudatários, na cultura ocidental, da correlação de fascismocolonialismo-racismo-sexualidade compulsória e servem de base para a justificação dos processos de normalização e, assim, de apoliticidade-despolitização próprios ao totalitarismo e seu núcleo básico, o medo, o estigma e a morte que nutrem a hegemonia pública do fascismo; (c) as minorias políticoculturais na esfera pública instituem uma perspectiva de descolonização da cultura e de descatequização da mente por meio da entabulação de uma voz-práxis direta, carnal, vinculada, política e politizante, em que suas
ABstRact: In the paper, we will thought on the idea of the transgender subject-group as a living aesthetical-political fiction that assumes itself as antifascist and antitotalitarian perspective from the facing of the logic of prepolitical, pre-cultural and a-historical identity which bases the fascist-colonialist-racistheteronormative compreensión of societyculture-anthropology, by emphasizing, since the affirmation of the transgender voice-praxis in its antifascist and antitotalitarian struggle, the founding relationality and politicity of this same society-culture-anthropology. In this sense, we will develop some basic points which are consequence of such a dynamic proper to the transgender thought-praxis, namely: (a) the political-cultural minorities - transgender, gay, black, indigenous, woman - are social constructions, historically located and politically performed, having not a prepolitical, pre-cultural and a-historical constitution; (b) they are consequence, in the Western culture, of the correlation of fascismcolonialism-racism-heteronormativity and serve as basis for the justification of the process of normalization and, then, of apoliticitydepoliticization proper to totalitarianism and its basic core, the fear, the stigma and the death, which nourish the public hegemony of fascism; (c) the political-cultural minorities in the public sphere institutes a perspective of decolonization of culture and of decatechization of mind by means of the streamlining of a direct, corporal, linked, political and politicizing voice-praxis,

* Doutor em Filosofia pela Pontifícia Universidade Católica do Rio Grande do Sul, PUCRS. Professor do Departamento de Filosofia da Fundação Universidade Federal de Rondônia. Email:leno_danner@yahoo.com.br 
singularidades e sua condição de menoridade (a violência vivida e sofrida como sujeito-grupocondição antinatural, moralmente decaído) serve como aguilhão crítico e politizador do fascismo-colonialismo-racismo-

heteronormatividade e como utopia ética de um mundo novo e de um novo ser humano; e, com isso, (d) a centralidade, para a democracia, do lugar de fala das e pelas minorias políticoculturais que, por meio de suas cores, sexos, gêneros, histórias e experiências, constituem-se como voz-práxis antifascista e antitotalitária que impulsiona a democracia, o pluralismo, os direitos humanos e a política enquanto eixos estruturantes dessa mesma democracia.

Palavras-Chave: Corpo Trans; Ficção Estético-Política; Parlamento dos Corpos; Politização; Desnaturalização; Fascismo in which their singularities as their condition of minority (the violence lived and suffered as antinatural and morally decayed subject-groupcondition) serve as critical and politicizing sting against the fascism-colonialism-racismheteronormativity, the same as ethical utopia for a new world and a new human being; and, with this, (d) the democratic centrality of the place of speak of and by political-cultural minorities which, by means of their colors, genders, histories and experiences, constitute themselves as antifascist and antitotalitarian voice-praxis that boost to more democracy, pluralism, human rights and politics as structuring axes of this same democracy.

KEYwords: Transgender Body; AestheticalPolitical Fiction; Parliament of the Bodies; Politicization; Denaturalization; Fascism

\section{"[...] a margem se cristalizava a cada dia" (Megg Rayara Gomes de Oliveira).}

"Não vos cansareis de nos diferenciar para poder converter-nos em vós mesmos? [...] O preço de vossa normalidade sexual é o nosso intersexualicídio. A única cura de que necessitamos é uma mudança de paradigma. Entretanto, como nos ensinou a história, posto que o paradigma da diferença sexual e de gênero é a garantia da manutenção de um conjunto de privilégios patriarcais e heterossexuais, esta mudança não será possível sem uma revolução política" (Paul Beatriz Preciado).

\section{CONSIDERAÇÕES INICIAIS}

Neste artigo, estudaremos o pensamento trans-queer de Paul Beatriz Preciado e de Megg Rayara Gomes de Oliveira com o intuito de refletir sobre - e de defender alguns argumentos básicos, a saber: (a) a crítica, a contraposição, o enfrentamento e a desconstrução, por parte do sujeito-grupo trans, da lógica da identidade que preside à compreensão fascista-colonialista-racista-heteronormativa relativamente às questões de raça, etnia, sexo e gênero, situação que leva à apoliticidade-despolitização deles a partir da fundação pré-política, pré-cultural e a-histórica desses sujeitos, práticas, valores e símbolos; (b) a percepção de que as minorias político-culturais de um modo geral e o sujeito-grupo trans em particular são construídos política e culturalmente a partir dessa dinâmica correlacionada de fascismo-colonialismo-racismo-sexualidade compulsória, a qual produz menoridade como anormalidade, antinaturalidade e negatividade exatamente enquanto autossustento e autolegitimação - o fascismo, sendo incapaz de autolegitimar-se de modo consequente (uma vez que seu núcleo é o medo, o estigma e a morte), o faz a partir da construção de um mal absoluto que põe em risco a ordem, a estabilidade e a pureza do grupo normalizado-naturalizado e que lhe motiva afetos e ações de autoproteção e/como enfrentamento salvíficos e messiânicos da sociedade e do sujeito normalizados (família, pátria, deus); (c) a entabulação de uma voz-práxis marcada pela descolonização da cultura e pela descatequização da mente, de cunho 
antifascista e antitotalitário, a qual parte da constatação de que o trans, o/a gay, a mulher, o/a negro, o/a índio não existem enquanto estrutura-sujeito-condição prépolítica, pré-cultural e a-histórica, mas como produção política e normativa nesse contexto próprio ao fascismo-colonialismo-racismo-heterossexualidade compulsória; e (d), com isso, a maturação, a vinculação e o protagonismo público, político e cultural do sujeito-grupo de minorias, sob a forma de uma voz-práxis estético-literária militante e da justificação de um lugar de fala que têm como cerne a visibilização da singularidade-alteridade desses sujeitos-grupos de minorias e a socialização catártica e altamente politizante das experiências de marginalização, de exclusão e de violência vividas e sofridas como minorias.

Nesse sentido, adentramos no argumento central desse texto, a saber, a ideia do sujeito-grupo trans como uma ficção estético-política viva de caráter antifacista e antitotalitário que combate a lógica fascista da identidade pré-política, pré-cultural e ahistórica produtora-reprodutora de menoridade por meio da afirmação da relacionalidade e da politicidade fundante da sociedade, da cultura, da linguagem, da história, das instituições, dos sujeitos, das práticas, dos valores, dos símbolos socialmente vinculantes. As minorias na esfera pública e como sujeito político-cultural possibilitam a desnaturalização do fascismo e, com isso, sua historicização e sua politização, uma vez que elas são exatamente o resto de normalidade, o esgoto da sociedade (na perspectiva fascista, obviamente) desde o qual o totalitarismo, o autoritarismo e o fundamentalismo conseguem justificar-se e à sua cultura do medo, do estigma e da morte, podendo, assim, homogeneizar, massificar e simplificar os sujeitos sociais, suas práticas e seus valores, para não se falar da história em comum. Aqui, o sujeito-grupo trans - e as minorias político-culturais de um modo mais geral - são ficções estético-políticas vivas que, por meio do corpo, do sexo, do gênero, da cor, dos trejeitos, das formas de ser, estar, amar e de resistir, implodem a submissão da cultura, da política, da linguagem e da história a uma caricatura de biologia e às fantasmagorias essencialistas e naturalizadas em torno à etnicidade, à racialidade, à sexualidade e ao gênero. Enquanto ficções estético-políticas vivas, é sua visibilidade, a visibilidade e a militância de e com seus corpos-sexos-gêneros-cores que impulsiona a mais democracia, a mais inclusão, participação e reconhecimento, ou seja, é exatamente a publicização, o enraizamento e o ativismo público, político e cultural das e pelas minorias que, enquanto práxis político-pedagógica, permitirá a maturação da democracia como perspectiva antifascista e antitotalitária calcada na afirmação e na promoção das diferenças por meio da política deliberativa, das instituições públicas e da educação democrática, a partir da centralidade do Estado democrático de direito, do pluralismo e dos direitos humanos.

Um esclarecimento é importante. Nós utilizaremos no texto a correlação fascismo-colonialismo-racismo-heteronormatividade para compreendermos o tipo de constituição e de desenvolvimento do processo de modernização ocidental iniciado no contexto das invasões, etnogenocídios e roubos praticados pelos colonizadores aos povos americanos, africanos e mesmo asiáticos, um movimento que se mantém como contínuo do século XVI para cá, com as nuances históricas específicas obviamente. É nesse contexto, aliás, como já mencionamos acima e como refletiremos mais adiante, que se pode falar do/a índio, do/a negro/a, do/a gay ou do/a homossexual, do/a trans, da mulher etc. Ligamos, portanto, a colonização eurocêntrica - e, depois, já no século XX, euronorcêntrica - a uma perspectiva fascista, colonial, racista e heteronormativa que ensaca em um mesmo tipo de tratamento menorizado e violento a estas diferentes classes de anormalidade, antinaturalidade e degeneração moral-normativa. Essa sugestão, aliás, nos é dada exatamente por teóricos da descolonização africana, tais como Aimé Césaire e Frantz Fanon, e da teoria social latino-americana, como Aníbal Quijano e Enrique Dussel, bem como por feministas negras e indígenas contemporâneas (como bell hooks, Angela Davis, Grada Kilomba, Djamila Ribeiro e Julieta Paredes - inclusive Judith Butler). Para eles/as, é com a colonização que efetivamente temos a implantação institucional de uma forma fascista de sociedade- 
cultura-consciência altamente simplificadora da vida social e globalmente controladora de comportamentos, práticas e processos de socialização-subjetivação por meio da naturalização, normalização e despolitização das identidades, das relações e da constituição dos e entre os sujeitos-grupos sociais, os quais já não apareceriam mais como construções político-normativas, mas sim enquanto dados pré-políticos, préculturais e a-históricos, caudatários da biologia (racismo biológico), da teologia (fundamentalismo religioso) e da economia (instrumentalismo econômico). A escravidão ampla de indígenas e de negros/as, o seu assassinato planificado, o roubo de suas terras etc. estão aí para comprovar esse estatuto de coisa, de objeto, de nãopoliticidade, de bestialidade a eles dado. Isso pode ser corroborado, como mostraremos mais adiante a título de exemplo, na própria concepção racista e eugênica de Charles Darwin, em seu incrível A Origem do Homem e a Seleção Sexual, em que a raça, o sexo, o gênero e a heterossexualidade compulsória aparecem interligados e, como fecho de abóboda, correlacionados com o eurocentrismo-colonialismo como seu pano de fundo (somente existem três raças: negra como África, branca como Europa e vermelha como América; só existem dois sexos: masculino e feminino; só existem dois processos de evolução antropológica: civilização como Europa, sociedades-povos semisselvagens como África e América; só existe um objetivo da evolução natural-cultural: procriação entre macho e fêmea, desde o prisma da heterossexualidade compulsória e do machismo, em que este mesmo macho é superior à fêmea por causa da conjunção de seleção sexual e seleção natural, aquela superior a esta, no caso dos mamíferos em geral e do ser humano em particular). Portanto, a correlação de fascismo-colonialismoracismo-heteronormatividade quer chamar a atenção para essa mutualidade, essa interseccionalidade e essa multimensionalidade do fenômeno do eurocentrismo em termos de colonização, que se constitui, mais uma vez segundo Aimé Césaire, no verdadeiro protótipo, na primeira e mais pungente experiência do e pelo fascismo.

\section{VISIBILIDADE E POLITIZAÇÃO: O CORPO-SEXO-GÊNERO-RAÇA QUE É POLÍTICO E POLITIZANTE}

A díade maioridade-menoridade é, na cultura ocidental gestada pela e correlacionada à modernidade europeia, mais do que um simples paralelo entre um sujeito educado, circunspecto e autônomo e um sujeito "senso comum", ignaro, fundamentalista, libidinoso e, portanto, heterônomo - alguém que usa a ciência, a moral e a cidadania, no primeiro caso, alguém que usa os preconceitos e misticismos cotidianos e vive de modo privatista (no duplo aspecto, como perspectiva não-política, como gozo animalesco), de outro; alguém que usa o corpo de modo púdico no primeiro caso, alguém que o usa de modo lascivo no outro; alguém escorreito em termos de juízo epistemológico-moral (sabendo diferenciá-los, aliás) e cujo discurso é lógico, coerente, baseado em razões, no primeiro caso, alguém contraditório em termos (ora fundamentalista, ora cético, ora moralista, ora lascivo, ora justo, ora injusto, discursa e age aparentemente preocupado com normas sociais, mas na sua vida privada ou mesmo entre os/as outros/as e com eles/as desrespeita e viola essas mesmas leis), basicamente incoerente e contraditório, no segundo caso. Ela reflete, sobretudo, uma contraposição racial, de sexo-gênero e civilizacional, raça e sexo/gênero e/como civilização, civilização e/como raça e sexo/gênero, para a qual gênero e sexo aparecem naturalizados, sempre imbricados à raça-cor, e vice-versa, como chaves interpretativas da cultura, da educação e dos modelos antropológicos válidos, hegemônicos. De modo muito interessante, essa díade aparece às vezes explícita, às vezes implicitamente na construção de imagens estético-políticas, de pressupostos epistemológicos e de autocompreensões normativas que separam a Europa e o sujeito europeu em relação às Américas e ao/à indígena americano/a, à África e ao/à negro/a africano/a, o homem (branco) em relação à mulher, o sujeito heterossexual em relação ao sujeito homossexual: Estado versus povos sem Estado, cultura versus selvageria, modernidade 
versus tradicionalismo, história versus ausência de história, civilização versus barbárie, indivíduo versus comunidade, mito versus ciência, clima frio versus clima quente ("não existe pecado do lado de lá do Equador"), brancura e civilização versus indianidadenegritude e selvageria, heterossexualismo versus homossexualismo, monogamia versus poligamia etc. O par maioridade-menoridade, portanto, indica fundamentalmente uma perspectiva antropológica e um paradigma epistemológico-político - um regime de verdade, utilizando o termo de Paul Beatriz Preciado - que produz normalidade e anormalidade, naturalidade e antinaturalidade, modelos exemplares e chagas-estigmas morais, e os produz concomitantemente, reciprocamente, um não existindo sem o outro, isto é, um regime de verdade não sendo possível a não ser por meio da própria produção da anormalidade-antinaturalidade, com a qual ele se justifica não por suas próprias condições internas, mas por aquilo que o anormal-antinatural é como negatividade, como inessencialidade (cf.: Preciado, 2019, p. 23-25; Oliveira, 2017, p. 60; Butler, 2003, p. 222-23; Kilomba, 2019, p. 71-92; Fanon, 1968, p. 26, p. 154). Esse ponto, aliás, é muito importante em termos epistemológico-políticos: um regime de verdade não se justifica por sua coerência interna e pela afirmação de um princípio primeiro uma causa incausada, ou a pressuposição dela - que, enquanto objetividade forte, evidente, inultrapassável, inegável, torna-se a pedra angular para a construção do edifício teórico e, nesse sentido, para a correlação de teoria e prática; ele se justifica exatamente pela construção da irracionalidade, da imoralidade, da antinaturalidade e da anormalidade como seu oposto, que lhe confere importância e pungência e que o vocaciona, o impele inexoravelmente à perspectiva salvífica, missionária e messiânica. Dito de outro modo, construindo a caverna é que se justifica a luz: não é a luz que ilumina a caverna, que permite a percepção e o enquadramento desta, senão que é a caverna que dá sentido e justificação à luz. Regimes de verdade, de cunho essencialista e naturalizado, portanto, somente subsistem, se sustentam e se vinculam intersubjetivamente pela construção e pela imposição de seu oposto, do mal em si, do anormal, do antinatural, o qual lhes dá todo sentido possível no que diz respeito à sua justificação, ao seu enraizamento e ao seu protagonismo social e institucional. Se não há este sujeito, momento e valor irracionais, como males absolutos, o regime de verdade cai por terra, perde seu sentido. Isso, de todo modo, mostra exatamente o sentido social, intersubjetivo, político e politizante das perspectivas antropológicas e dos pressupostos epistemológico-políticos e, em nosso caso, da díade maioridademenoridade, da qual refletíamos acima; eles não são pré-políticos, mas políticos; não são pré-culturais, mas culturais; não são pré-sociais, mas sociais; não são a-históricos, mas históricos - eles são e dependem de relacionalidade e politicidade fundantes.

Maioridade e menoridade são assumidas, em consequência, como construtos normativos que, pela sua perspectiva essencialista e naturalizada de fundo (isto é, por seu fundamentalismo) estabelecem lugares sociais, valores intersubjetivos e um padrão último de verdade a partir dos quais a vida sociocultural de um modo geral e as instituições comuns em particular organizam, orientam, implantam e delimitam os processos de socialização e de subjetivação, eminentemente imbricados e dependendo exatamente desse núcleo antropológico, epistemológico e político uniforme assumido, utilizado e imposto por nossas instituições comuns. Daqui surgem três pontos fundamentais à modernização ocidental, ao protagonismo do horizonte euronorcêntrico relativamente às periferias e aos sujeitos periféricos a essa mesma modernização ocidental: primeiramente, a centralidade das próprias instituições sociais no que diz respeito a normalizar regimes de verdade que operam nessa perspectiva dualistamaniqueísta, os quais produzem um espaço-sujeito-valor legítimo e exemplar correlatamente à construção de um espaço-sujeito-valor denegrido (a utilização deste adjetivo que, na sua gênese, possui cunho racista não é acaso); segundo, a própria ideia de um espaço-sujeito-valor normal e natural, bem como de um espaço-sujeito-valor anormal e antinatural, que deixam de ser percebidos como constructos políticos, cultural e historicamente localizados, relacionalmente estruturados, para se tornarem pressupostos pré-políticos, pré-culturais e a-históricos - ou seja, por meio dessa 
normalização e naturalização, tem-se a despolitização dos sujeitos, das relações, das práticas e dos valores socialmente vinculantes. Não por acaso, a biologia e, depois, a antropologia (que em um primeiro momento é levada a efeito por naturalistas como Charles Darwin ou que nele se inspiram - vide o racismo, a eugenia e a contraposição entre sociedades modernas e sociedades arcaicas, que demarcam a segunda metade do século XIX e a primeira metade do século XX na biologia e na antropologia) tornam-se o paradigma explicativo que se utiliza da brancura-heterossexualidade-eurocentrismo como a condição antropológico-civilizacional última que deve ser justificada a partir de sua contraposição com estes estágios evolutivos rudimentares que nos são dados pelos/as indígenas e negros/as, com estes corpos escuros, libidinosos ou anormais que nos são dados pelos/as negros/as, pelos/as indígenas, pelos/as homossexuais. Terceiro, portanto, e como consequência direta dos dois passos anteriores, a tendência totalizante desse mesmo processo de modernização ocidental, que o impele de "modo egocêntrico" (na expressão de Enrique Dussel - cf.: Dussel, 1993, p. 75-118) para além de si, no sentido de colonização epistêmica (colonialidade cultural, na fala de Aníbal Quijano cf.: Quijano, 1992, p. 11-20; Quijano, 2005, p. 117-142), quando não econômica e militar, dos/as outros/as da modernidade (outros/as da modernidade assumidos/as como base dos próprios discursos filosóficos-sociológicos da modernidade enquanto um dado antropológico a-político, não como relacionalidade e politicidade própria ao contato em termos de colonialismo) ${ }^{1}$.

"O que, porém, a nós interessa", diz-nos Charles Darwin relativamente à reconstrução e à explicação das práticas culturais próprias aos sujeitos civilizados e como condição para o seu entendimento, "é o comportamento dos homens nos tempos primordiais, e o nosso único elemento de julgamento sobre esse assunto é o estudo dos costumes das populações no estado semicivilizado ou selvagem" (Darwin, 1974, p. 660; destaques são nossos). Ou seja, o único elemento fundador e justificador do par maioridade-menoridade consiste exatamente na construção dessa diferença antropológica fundante em que o sujeito maior, obviamente autopressuposto como tal, afirma-se por meio da explicitação do que esse/a outro/a menor não é; de modo mais específico, o sujeito europeu branco, burguês e heterossexual - que é o padrão normativo, normal e natural de Darwin no seu magnífico A Origem do Homem e a Evolução Sexual - afirma-se enquanto tal pela negativação do que o/a negro/a e o/a indígena não são. Por isso, inclusive, no texto em comento, a referência ao/à negro/a e ao/à indígena sempre se utiliza do termo "eram", "foram", isto é, do passado, como sujeitos do passado, além de metáforas ligadas à zoologia (cf.: Darwin, 1974, p. 711712; Fanon, 1968, p. 31-32). É importante mencionar-se que não podemos nos enganar com a passagem acima, no sentido de que seria apenas um pressuposto teórico capaz de explicar e dar sentido a um conjunto de fatos aparentemente amplos e desconexos, que ainda nos são obscuros, um artifício epistêmico garantidor da explicação do que somos hoje, situação que implicaria naquilo que fomos ontem, o que somos hoje como resultado do que fomos ontem, o presente (heterossexualismo branco, eurocêntrico e burguês) como resultado do passado (indígena/negro/a como selvageria e degeneração). Também não podemos simplesmente cair na ingenuidade de aceitar que tal juízo constitui-se meramente como um fato científico destituído de vinculação normativa e de enraizamento social, cultural e político - no caso do livro em comento, as comparações morais são por demais óbvias para aceitarmos a ideia de que a inferioridade cultural e intelectual de negros/as e índios/as, quando comparada ao modelo do homem branco europeu, seja apenas um elemento factual. Há, portanto, uma noção essencialista e naturalizada, apolítica-despolitizada, de homem, sociedade e valor que subjaz ao par maioridade-menoridade assumido pela modernidade ocidental como eixo estruturante de sua autolegitimação, ou seja, da construção caricata e fantasmagórica dos/as outros/as da modernidade ${ }^{2}$. Trata-se aqui diretamente da justificação de um padrão atual, contemporâneo, portanto, de um sujeito normalizado que é caudatário de um processo naturalizado de evolução totalizante, homogeneizante e unilinear, que vai do menos para o mais, do passado para o presente, do inessencial para o efetivo - um 
processo, aliás, que somente pode ser compreendido pelo sujeito do presente, não pelo sujeito do passado ${ }^{3}$. Não se trata, no livro de Darwin acima citado, apenas da explicação de por que o homem europeu branco é superior cultural, civilizacional e intelectualmente ao negro e ao indígena, bem como à própria mulher branca e negra e indígena, mas também da normalização e da naturalização desse modelo, com sua correlata despolitização e afirmação a-histórica que, por exemplo, elidem em toda a obra a perspectiva política e histórica constituída pelo colonialismo-racismoheteronormatividade, o qual, como é bastante corriqueiro nas filosofias europeias $-\mathrm{e}$, nesse caso, na biologia do século XIX até meados do século XX com sua constituição racista, heteronormativa e eugênica (é este, aliás, o caso de Darwin), a qual assume como pano de fundo a perspectiva colonial própria ao eurocentrismo, construída por ele - o colonialismo-racismo-heteronormatividade simplesmente não é citado como correlato da modernidade-modernização ocidental, como causa desse suposto atraso próprio aos/às indígenas americanos/as e aos/às negros/as africanos/as, ou do homem branco em relação à mulher branca.

No mesmo diapasão, já que estamos comentando de passagem sobre Charles Darwin e seu paradigma biologicista acerca da produção - nesse caso apolítica, despolitizada e a-histórica - de maioridade e menoridade , a própria tese central da referida obra gira em torno da diferenciação racial e de gênero entre os múltiplos grupos humanos existentes - em Darwin, apenas três grupos, branco, indígena e negro, sem nenhuma especificação mais ampla -, correlatamente ao fato da diferenciação entre homem e mulher - em Darwin, mais uma vez, apenas dois sexos-gêneros e, então, sexo como gênero, gênero como sexo, homem-pênis-masculino, mulher-vagina-feminino. "Constitui circunstância notável", continua Darwin, "que a diferença entre os dois sexos, no que diz respeito à cavidade craniana, aumente com o desenvolvimento da raça, de modo que o macho europeu supera a fêmea mais do que um negro supera uma negra" (Darwin, 1974, p. 651). Note-se, nesta passagem, duas ideias fundamentais: diferenças entre os dois sexos; desenvolvimento da raça. Primeiramente, é importante retomar-se exatamente essa ideia de que o sexo-gênero depende de modo fundamental da condição racial do sujeito. Vimos na passagem a ideia de que essa condição racial, que é a base do desenvolvimento ou do subdesenvolvimento cultural-civilizacionalcognitivo de qualquer povo-sujeito, define mais diferenciação cognitiva entre o homem branco europeu e a mulher branca europeia (e somente haveria brancura na e com a Europa, Europa como brancura) e muita similaridade intelectual entre o homem negro africano e a mulher negra africana (e só haveria negritude na África, nas colônias, África como negritude). Por outras palavras, devido à sua estrutura racial, o homem branco europeu é muito mais inteligente que a mulher branca europeia, ao passo que o homem negro africano, novamente por causa de sua condição racial negra, tem uma capacidade intelectual muito similar à da mulher negra africana - chegando às vezes a ser correlacionado aos símios ou a uma situação de semi-selvageria. Raça, biologicamente (pré-politicamente, a-historicamente) estruturada, nesse caso, define o nível civilizacional, cultural e cognitivo dos grupos humanos e, com isso, a própria diferenciação ou não de sexo e de gênero - o colonialismo sequer é aventado, aqui, como um fator explicativo da desigualdade e, portanto, tudo se deve à raça, à biologia. Em segundo lugar, a própria dinâmica evolutiva dos grupos humanos gira em torno à procriação heterossexual. $O$ heterossexualismo e a procriação, nesse sentido, não apenas se constituem no princípio explicativo fundamental de como nos diferenciamos racialmente e em termos de sexo-gênero, mas também são afirmados como o padrão normalizado e/porque natural a partir do qual se estabelece (a) a existência de apenas dois gêneros, diretamente correlacionados ao sexo, de cunho biológico-fisiológicogenético, bem como (b) a centralidade da luta sexual em torno à procriação (seleção sexual), à qual tudo o mais está subordinado, inclusive, no caso de Darwin, a seleção natural. O sujeito homossexual, o sujeito LGBTQ+ simplesmente é excluído da história evolutiva humana, da biologia à cultura, da cultura como estágio biológico superior, por assim dizer, que se reduz, como se pode ver, à correlação de sexo-gênero-raça 
biologicamente fundados, apolítica e a-historicamente concebidos. E, nessa história da evolução humana, que é a história, no caso de Darwin, do sexo-gênero-raça biológico, é exatamente a história da raça branca heterossexual de um modo geral e do homem branco aristocrático-burguês europeu que estamos assistindo de modo explícito, quer dizer, de modo naturalizado, a-histórico e apolítico-despolitizado 4 .

$100 \quad O$ que vemos aqui é a construção de uma lógica da identidade, utilizando-nos novamente das reflexões de Paul Preciado, para a qual a socialização-subjetivação é determinada a partir de critérios biológicos e/ou fortemente etnocêntricos que, como dissemos acima, assumem um sentido a-histórico e pré-cultural, uma identidade, nesse sentido, apolítica e despolitizada, carente de relacionalidade (em certos casos, profundamente xenofóbica e egocêntrica). Há uma estrutura morfológico-fisiológica de caráter genético e hereditário - que embasa a autocompreensão normativa do e pelo sujeito, bem como, antes desse mesmo sujeito, a estruturação da sociedade, suas instituições, suas práticas e seus valores em comum; há, ademais, uma noção mistificada, fantasiosa e distópica em que um modelo racial-étnico-bélico-religioso ahistórico perdido nas brumas do tempo embasa a constituição de uma posição institucional e cultural totalizante, unidimensional e ao mesmo tempo fechada, disposta à extinção de identidades alienígenas, não reconhecidas como tal (pensemos, aqui, no ideal do branco próprio à eugenia euro-americana - e com suas ramificações nas colônias então em modernização; no arianismo cultural; na Ku-Klux-Klan) - em geral, aqui, uma caricatura de biologia (fundada na ideia de raça, racialidade, racismo) e uma fantasia étnico-religiosa justificam a compreensão fascista de sociedade, de cultura, de instituição, de valor, de sujeito etc. Essa identidade morfológico-genética fantasiosa ramifica-se na correlação de sexo-gênero-raça: nosso corpo biológico e nossa vinculação étnica fantástica conferem uma identidade pessoal normativa e um modelo antropológico amplos que legitimam um campo de normalidade ou de legitimidade, por meio da construção consentânea de uma esfera de negatividade que, por sua condição antinatural, degenerada e anormal, serve como parâmetro epistemológico-político seja para a institucionalização de um processo estrutural de normalização, de unidimensionalização dos corpos e dos imaginários em uma coletividade unificada e homogênea, seja para o diagnóstico, o tratamento e/ou a exclusão desse sujeito anormal-antinatural, inclusive para o etnocídio-genocídio dos/as anormais. Note-se que essa identidade apolítica-despolitizada e a-histórica simplesmente não pode escapar dessas consequências amplas no que se refere à aplicação de um paradigma genérico à pluralidade humana, ou seja, assumir uma compreensão naturalizada, a-histórica e apolítica-despolitizada da identidade do sujeito equivale a concomitantemente justificar critérios de exclusão, de degeneração e de estigmatização de outros sujeitos-grupos, a partir de uma ampla mistificação, de uma crua simplificação e de uma grotesca hipostasiação de modelos raciais e xenofóbicos, levando-se ao fascismo. Regimes de verdade, nesse sentido propriamente biológico-xenofóbico, criam também campos de concentração; o sujeito maior cria também o sujeito menor; a lógica da verdade é também a fundação da caverna de Platão - a caverna não está lá, como anterior à verdade, senão que aparece e é justificada de modo correlato à fundação de uma concepção objetiva de mundo de caráter essencialista e naturalizada, centralizada e monopolizada por alguns, apenas acessada por alguns, instituições e/ou sujeitos. Nesse sentido, não é a verdade que se constitui na luz a iluminar as trevas, senão que é a afirmação permanente das trevas que legitima à própria luz; não é o normal que explica e objetifica - e até cura - o anormal, mas este que confere sentido, vocação e justificação àquele. A fantasia do fascismo, em termos de sua autojustificação e de sua vinculação social, exige em última instância a produção da menoridade, não sendo suficiente a assunção para si do racismo biológico e da xenofobia fundamentalista.

Do sexo-gênero naturalizado vai-se diretamente à raça percebida em termos biológicos e, desta, à forte perspectiva étnico-xenofóbica que subjaz, no caso da Europa dos séculos XIX e XX (e XXI!), como critério de fechamento destas sociedades à crescente onda de refugiados originados da - produzidos pela - falência da globalização 
econômico-cultural, uma perspectiva étnico-racial-xenofóbica que, diga-se de passagem, foi um dos motes centrais dos sistemas colonialistas dos séculos XIX e XX e dos regimes totalitários e fascistas do século XX (como diz Aimé Césaire, não se separa colonialismo, racismo e fascismo, senão que são características e atitudes próprias ao colonialismo europeu e, de modo mais amplo, da própria modernização ocidental) (cf.: Césaire, 1978, p. 13-16; Memmi, 1967, p. 47-51; Fanon, 1968, p. 26-39). Se as feministas negras, a exemplo do maravilhoso trabalho de bel hooks, Angela Davies, Grada Kilomba e de Djamila Ribeiro, ou mesmo de Judith Butler, já chamavam a atenção para o fato de que não é possível falarmos em uma perspectiva feminista que dissocie sexo-gênero e raça como realidades estanques e não influenciáveis (ou mesmo que separem a reflexão sobre a condição, o lugar e o papel da mulher em qualquer sociedade relativamente às condições políticas, culturais e econômicas) (cf.: hooks, 2019, p. 44-63; Davies, 2004, p. 93-104; Kilomba, 2019, p. 101-103; Ribeiro, 2017, p. 13-31; Ribeiro, 2018, p. 108-111; Butler, 2003, p. 20), pudemos, por outro lado, perceber acima, por meio das reflexões desde Darwin, que as próprias bases disso que poderíamos chamar, seguindo ao pensamento queer e feminista, de um modelo de verdade e de uma lógica da identidade calcados na correlação de sexo-gênero-raça biologicamente estruturados e justificados com o sujeito heterossexual europeu, branco e burguês (interessantemente, estes quatro qualificativos aparecem em cheio no trabalho de Darwin, como já salientamos acima), também assumem como seu complemento inextricável essa compreensão naturalizada que intersecciona sexo como gênero, sexo-gênero e racialidade-etnicidade e, em tudo isso, sexo-gênero-raçacivilização como momentos absolutamente imbricados de uma mesma compreensão genérica e totalizante de sociedade e de sujeito.

Um regime de verdade e uma lógica da identidade, ou seja, a assunção de um paradigma objetivo que assume uma base normativa, um modelo epistêmicoantropológico e um caminho civilizacional-modernizante constitutivo-evolutivo universais, pode adquirir duas variantes, que, por óbvio, não estão interligadas necessariamente, mas que se aproximam profundamente em termos dessa produção do par maioridade-menoridade como um pressuposto antropológico a-histórico e apolíticodespolitizado, e não como um mero modus vivendi caudatário de mais ou menos acesso aos logros da cultura civilizada (e autopressuposto por essa mesma cultura "civilizada", como vimos em passagem de Habermas acima, em nota de rodapé). No primeiro caso, conforme pudemos perceber em Darwin, o regime de verdade e a lógica da identidade são dados de modo pré-político, pré-cultural, pré-social e a-histórico, a partir da utilização da biologia como chave interpretativa da cultura, um modelo que a filosofia contemporânea, em especial desde a segunda metade do século XX por meio das experiências do colonialismo, do totalitarismo e do fascismo, e desde a centralidade do pluralismo, da diversidade, passou a recusar peremptoriamente. A biologia, afirmada desde uma perspectiva simplista, de todo modo, interligada ao fundamentalismo religioso, continua a ser um dos últimos redutos desse regime de verdade e dessa lógica da identidade que imbrica ferreamente sexo e gênero - e que em muitas ocasiões correlaciona sexo-gênero-raça, principalmente nas perspectivas fascistas e fundamentalistas. No segundo caso, esse regime de verdade e essa lógica da identidade são justificados de modo mais sutil e giram em torno da diferenciação epistemológicopolítica entre tradicional e pós-tradicional, metafísico e pós-metafísico que se tornou a grande base das ciências humanas e sociais euronorcêntricas contemporâneas: trata-se da ideia de que há uma evolução antropológica comum, linear e contínua ao gênero humano, a qual garante identidade mínima às diferentes sociedades-culturasconsciências e que permite pensar-se em uma noção de consciência cognitivo-moral unívoca, uma evolução que é significada pelo fato de que - e a sociedade-culturaconsciência moderna ou euronorcêntrica é o exemplo que permite esse discurso alcançamos gradativamente uma perspectiva descentrada marcada por uma posição não-egocêntrica da consciência moral subjetiva e não-etnocêntrica da sociedadecultura-intersubjetividade. Novamente, aqui, a evolução da Europa como modernidade 
é o quadro referencial que naturaliza e despolitiza a evolução do gênero humano, que se confunde com a própria Europa, e, portanto, toda a evolução do gênero humano e o tipo de condição presente e futura a serem assumidos em termos interculturais - valores e práticas comuns, formas de produção econômica e de trato com a natureza, epistemes várias e, obviamente, sujeitos plurais - estão subsumidos (a) ao fato de que "[...] o nível 102 pós-tradicional se torna acessível em uma cultura, e mais precisamente na cultura europeia [...]" (Habermas, 2012, p. 355), bem como (b), enquanto necessidade direta, à própria questão de que o nível pós-tradicional da sociedade-cultura-consciência gestado pela modernidade europeia, o único paradigma normativo capaz de garantir crítica, reflexividade e justificação universalistas (para Habermas e Honneth), somente pode ser provado, conforme palavras de Axel Honneth, por meio de uma comparação com sua antítese, com o pré-moderno como déficit universalista:

Nesse sentido, é natural adotar para a situação inicial do processo de formação a ser descrito uma forma de interação social em que aqueles três padrões de reconhecimento estavam ainda entrelaçados uns nos outros de maneira indistinta; a favor disso pode depor a existência de uma moral arcaica e interna de grupo, no interior da qual os aspectos da assistência não estavam separados completamente nem dos direitos de membro da tribo nem de sua estima social (Honneth, 2003, p. 266-267; os destaques são nossos. Cf., ainda: Habermas, 2012, p. 90-141).

O que Honneth quer dizer é que, em sociedades-culturas-consciências não modernas, não europeias, o reconhecimento comum e a justificação universalista - e, portanto, também a crítica social e a transformação política - não seriam possíveis, por causa da centralidade das perspectivas étnicas, raciais e de parentesco vigentes nestas. Somente na modernidade ocidental o universalismo epistemológico-moral, caudatário da descentração do mundo e da racionalização cultural, é tornado possível, a partir da constituição de uma posição social, cultural e cognitiva pós-metafísica ou póstradicional, via racionalização sociocultural. Em relação a esse exclusivismo da modernidade ocidental e à consequente deslegitimação do não moderno como negatividade e como algo-alguém sem qualquer relação com a própria modernidade (note-se a elisão do colonialismo por parte das fillosofias europeias!), Habermas complementa: "[...] a descentração da compreensão de mundo e a racionalização do mundo da vida são condições necessárias para uma sociedade emancipada" (Habermas, 2012, p. 146; o destaque é de Habermas). Só a modernidade europeia e a partir dela mesma gera universalismo, crítica, transformação, emancipação e reconhecimento, para si e para os/as outros/as dela. Como se pode perceber, estes dois exemplos próprios à perspectiva cultural e institucional euronorcêntrica explicitam a naturalização de um paradigma antropológico que necessita construir uma lógica da identidade que é também uma lógica da exclusão, que somente se afirma em sua condição como universalidade, isto é, como presente e futuro do e para o gênero humano, como intérprete, juiz e guia dele e em nome dele, na medida em que constrói um passado ou uma condição-sujeito-valor deficitário que aquele superou, que aquele já não é mais, que aquele pode corrigir. A relacionalidade e a politicidade entre o normal e o anormal, entre o natural e o antinatural, entre o moderno e o arcaico, entre o heterossexual e o homossexual ficam apagadas, deslegitimadas; parece como se eles simplesmente estivessem dados a nós enquanto unidades independentes e sem reciprocidade, que evoluíram cada um a seu modo e por seus próprios meios, quando na verdade são e somos construções intersubjetivas, politicamente realizadas. Modelos antropológicos são gestados e efetivados historicamente, relacionalmente, politicamente. A negação dessa dependência, dessa relacionalidade e dessa politicidade entre sujeitos, valores e perspectivas múltiplos, que, por vários fatores, gradativamente passam a interagir, implica exatamente na instituição e na validação de um processo amplo - que vai da cultura para a política, das instituições para a epistemologia - de produção de maioridade e de menoridade, de normalidade e de anormalidade, de naturalidade e de antinaturalidade. Com efeito, tanto no exemplo de Darwin quanto no exemplo de 
Habermas e de Honneth, tem-se a utilização do modelo antropológico específico ao homem europeu, heterossexual, branco e burguês (Darwin - justificação biológica) e da condição pós-tradicional e descentrada própria à modernidade europeia (Habermas e Honneth - justificação que pressupõe o caráter comum, linear e unidirecional do gênero humano como um todo, de identidade comum, por meio da racionalidade culturalcomunicativa e da ideia de reconhecimento social) como substratos para a avaliação e justificação do ego, do si mesmo, da própria identidade, mas também para a negativação do outro de si, da diferença - o sujeito moderno é o sujeito do presente, e somente ele pode conhecer a si e ao outro de si como passado, insuficiência e negatividade - menoridade; o sujeito não moderno é o arcaico, o mítico, e este não conhece a si e nem aos outros de si. Aqui, somente a identidade, seja ela biológica, seja ela etnocêntrica e essencialista (embora Habermas e Honneth neguem peremptoriamente que assumam o conceito de modernidade de modo etnocêntrico, mas como identidade comum do gênero humano, de cunho transhistórico e intercultural), permite tanto a autocompreensão pessoal quanto a compreensão desse outro anterior, arcaico, negro/a, indígena/a, gay, trans etc. Por outras palavras, o/a negro/a, o/a indígena, o/a gay, o/a trans, o/a outro/a da modernidade são produzidos epistemológica e politicamente no mesmo movimento e como exigência e consequência diretas da autoprodução do sujeito moderno, seja nas perspectivas heterossexuais, raciais e eugênicas representadas por Darwin, seja em posições ligadas a um universalismo póstradicional moderno como é o caso de Honneth e de Habermas, e são produzidos a partir de um movimento epistêmico-político curioso e fundamental: o sujeito moderno é o sujeito da compreensão de si e do passado humano representado por aqueles outros sujeitos; por isso, o sujeito moderno é o sujeito do presente e todos os outros são sujeitos do passado. Se em Darwin o sexo-gênero-raça, que serve de base para a compreensão e o mapeamento da evolução humana, está associado ao homem europeu, branco, heterossexual e burguês (e isso de modo explícito: ele é o ápice evolutivo de uma condição humana em que o/a negro/a e o/a índio/a representam os primórdios e, enquanto tal, ele serve de modelo antropológico para a mensuração do sentido arcaico, às vezes bizarros, destes/as últimos/as, inclusive reconstruindo - ele e somente ele essa história evolutiva do gênero humano em termos naturalistas), em Habermas e em Honneth o gênero humano confunde-se com a própria modernidade, a partir da construção de uma perspectiva dualista em que essa mesma modernidade se afirma em sua singularidade e universalidade por meio da construção desse outro genérico, do não-moderno como arcaísmo e passado, como não-sujeito do presente. Obviamente, Habermas e Honneth estão muito longe de justificar biologicamente, por meio da pressuposição de uma raça-sexo-gênero pré-político, pré-cultural e a-histórico, seja a naturalidade e o escalonamento de sexo-gênero, seja sua consequente estigmatização (como consequência da dualidade de sexo-gênero e de sua correlação - pênis somente com vagina, vagina somente com pênis etc.), ao contrário da perspectiva darwiniana. Como dizíamos, a justificação do par maioridade-menoridade ou é feita explicitamente a partir de pressupostos essencialistas e naturalizados, como vimos na utilização da biologia como base de compreensão e de justificação da cultura, ou por meio de uma perspectiva antropológico-epistemológica mais implícita que explícita acerca da diferença entre moderno e arcaico, pós-tradicional e tradicional, pós-metafísico e metafísico, a qual assume uma identidade antropológica uniforme ao gênero humano que descamba na ideia de que a modernidade ocidental é a realização plena e universalista desse mesmo gênero humano, seu presente, ao passo que os/as outros/as dela são passado, arcaísmo, tradicionalismo em geral. Em ambos os casos, a evolução do gênero humano é vista de modo unitário, linear e progressivo, indo do menos para o mais, do inferior para o superior e, não tão surpreendentemente, do não-europeu para o europeu (seja o homem branco, heterossexual e burguês no caso de Darwin, seja o modelo não-egocêntrico de sujeito moral e a perspectiva não-etnocêntrica de sociedadecultura europeus no caso de Habermas e de Honneth). Em ambos os casos, assim, o sujeito do presente fala do e sobre o sujeito do passado: o homem branco, europeu, 
heterossexual e burguês reconstrói e interpreta por meio da biologia todo o processo evolutivo humano que levou a si como atualidade pura e presente efetivo, a partir do estudo das populações semi-civilizadas e dos sujeitos arcaicos como passado, inatualidade, inessencialidade (Darwin); a sociedade-cultura-consciência europeia moderna como universalidade pós-metafísica ou pós-tradicional reconstrói o processo

104 evolutivo próprio ao gênero humano no sentido de provar-se exatamente como essa universalidade aberta às diferenças, racionalmente estruturada, como esse apogeu do gênero humano (apogeu=universalidade pós-metafísica, pós-tradicional) de todas as demais sociedades-culturas-consciências como tradicionalismo em geral (Habermas e Honneth). Mudam os jogos de conceitos e algumas consequências importantes, mas o núcleo central é o mesmo, no que tange ao pensamento euronorcêntrico, a saber: a díade maioridade-menoridade, normal-anormal, modernidade e outro/a da modernidade. E, portanto, sua consequência, isto é, a correlação de eurocentrismocolonialismo-racismo, de raça-sexo-gênero permanece pulsante como um dos núcleos fundamentais do pensamento e da cultura europeus.

O par maioridade-menoridade, com sua dependência, imbricação e intersecção básicas, implica, quando o vemos e o analisamos desde o prisma do colonialismo, do racismo, do machismo, da homofobia, da transfobia, do "fundamentalismo" islâmico, do "mito" indígena, exatamente a desnaturalização e, portanto, a politização dos discursos e das práticas que constroem-no, justificam-no e impõem-no. A comparação entre sexos, gêneros, raças e sociedades-culturas não pode ser feita por um nível meta que, como reconhecem o próprio Habermas e o próprio Honneth, parte da pressuposição de que sua sociedade-cultura-consciência - a Europa - representa a condição presente do gênero humano, síntese e estágio final da evolução do gênero humano, estabelecendo uma condição passada que é correlacionada aos/as outros/as da modernidade, ao arcaico, ao tradicional. $\mathrm{O}$ mesmo vale para a questão de sexo-gêneroraça, em que a fisiologia-morfologia-genética é utilizada para estabelecer uma correlação entre corpo e autocompreensão normativa, raça e condição civilizacionalcultural-cognitiva - no caso de Darwin, o heterossexualismo europeu, branco e burguês. Tais pressuposições assumem gradativamente um status mais sólido do que meros artifícios intelectuais e epistêmicos para a formulação de hipóteses e, no caso da filosofia, para a justificação da normatividade social; elas se tornam diretamente condições antropológicas de fundo que embasam a constituição prática das instituições, seus sistemas de saber e, como consequência, orientam e definem tipos modelares de processos de socialização e de subjetivação, com a estigmatização de sujeitos-gruposvalores que caem fora desse regime antropológico naturalizado. Presume-se que certo tipo de civilização, de cultura, de corpo, de cor, de gênero, de episteme etc. é atual, modelar, paradigmático, e, ao se naturalizá-lo, coloca-se todos os outros em dependência daquele, inclusive estabelecendo-se uma genealogia evolutiva que culmina exatamente nesse pressuposto de fundo como o ápice, ao qual todo o restante está subordinado e, obviamente, inferiorizado. É aqui, enquanto enfrentamento dessa perspectiva naturalizada, a-histórica e apolítica-despolitizada, que podemos perceber uma redefinição das minorias político-culturais que demarca e dinamiza de modo fundamental a cultura contemporânea, uma redefinição que, aliás, foi assumida e estilizada por essas mesmas minorias político-culturais de modo fortemente político, como uma forma ao mesmo tempo de desvelamento, de crítica e de combate às situações de violência simbólico-material geradas pela perspectiva biologicista, xenofóbica, mistificada e fundamentalista de sexo-gênero-raça justificada e imposta pelo eurocentrismo-colonialismo, e de reafirmação e de reconstrução de sua própria autocompreensão, agora como positividade, e não mais como negatividade, agora como maioridade, não mais como menoridade.

A menoridade, para começo de conversa, representa, nas perspectivas racistas e fundamentalistas eurocêntrico-coloniais, uma situação antropológica ligada à correlação de sexo-gênero-raça e expressa um sujeito-grupo decaído, bestializado, intelectualmente limitado, arcaico, degenerado, anormal, imoral. O sujeito-grupo 
menor, nessa perspectiva eurocêntrico-colonialista, deveria ser tutelado, uma vez que, por seus déficits, não poderia ser um sujeito público (maioridade significa ser um sujeito público), mas apenas privado: seu lugar é a cozinha, o armário, o mato ou a fazenda - a invisibilidade, o silenciamento e o privatismo, enfim -, e não a esfera pública, as instituições públicas; seus valores devem ser banidos do convívio social e suas práticas devem ser escondidas, punidas se objetivarem publicizar-se, mostrar-se aos olhos e fazer-se escutar pelos ouvidos dos/as normais, dos/as puros/as, dos/as evoluídos/as. E o sujeito-grupo maior assume-se como seu tutor, como seu guia, atribuindo-se uma vocação civilizacional e humanista-humanizadora. Em última instância, a menoridade implica em um estigma visível, impossível de ser escondido, como a cor da pele, os trejeitos afeminados, a voz infantilizada, o raciocínio limitado, o comportamento animalesco, a depravação-corrupção moral - daí, inclusive, a necessidade de que o sujeito-grupo menor seja invisibilizado, silenciado, escondido dos olhos do público. A menoridade é uma chaga e o sujeito-grupo menor é visto como chaga, a partir dela, como ela. Qual chaga? A cor - "Seu negro! Seu índio!". A sexualidade: "Seu viado! Sua bicha!". O gênero: "Mulherzinha!", "Mariquinhas!". A animalidade-bestialidade: "Seu macaco! Sua cadela! Sua vaca! Seu selvagem!". As metáforas da exclusão: "A situação está negra!" "Mãos brancas como a de uma mulher!" "Preguiçoso como um índio!, "Fundamentalista como um muçulmano!" etc. A visibilidade do sujeito-grupo menor, quando ele tem coragem de aparecer, é o mesmo que uma violação da normalidade; o sujeito-grupo menor, quando está em público, aparece como negatividade, como depravação, como selvageria. E, enquanto tal, é novamente excluído, invisibilizado, calado, empurrado para os cantos escuros e não visíveis de nossa sociedade e de suas instituições repressivas. Ademais, sua deslegitimação normativa (como doença, como anormalidade, como antinaturalidade, como animalidade, como depravação, como arcaísmo), sua exclusão social e o tratamento institucionalmente violento ao qual são submetidos tanto pelos poderes nucleares da sociedade quanto pela maioria, pelos/as normais, não são vistos por esse sujeito-grupo normal como uma forma de preconceito, de segmentação, de racismo, de homofobia, de transfobia, de machismo etc., porque a normalização e a naturalização implicam em apoliticidade e despolitização, em interrupção da crítica, em uma vida não-reflexiva, fechada à alteridade, e na constante imposição de uma concepção antropológico-ontológica e epistemológico-política forte, sem mediações institucionais, sem sensibilidade moral e sem moderação prático-discursiva - estabelecendo-se uma guerra santa explícita, sem pudor e permanente, baseada no racismo biológico, no fundamentalismo religioso e no fascismo político-cultural. A produção de menoridade e a violência simbólico-material contra o sujeito-grupo menor são dessubstantivadas, isto é, aparecem não como uma forma de agressão e de negação efetivas, nuas e cruas, mas como uma fantasmagoria da suposta vítima, que se faz de vítima e, portanto, que se vitimiza em nome de sua condição, quando, na verdade, para o fascismo, essa suposta vítima é o verdadeiro problema a ser resolvido por meio de sua eliminação; no mesmo diapasão, a atitude fascista-racista-moralista já não aparece, devido à naturalização e à normalização - e, portanto, à apoliticidade-despolitização - da questão de raça-sexogênero, como uma forma de violência e de usurpação de direitos, mas como uma cruzada salvífica, corretiva, uma vocação missionária e messiânica pela verdade, escorada na verdade, a favor da verdade. Nesse sentido, sua (da vítima) condição como menor, para o sujeito-grupo normalizado, não se deve a uma relacionalidade política, mas a uma condição intrínseca a esse sujeito-grupo menor e, assim, esse sujeito-grupo menor pode ser enquadrado de modo fascista, racista, colonialista, sexista - às vezes, todos os qualificativos imbricados no sujeito-grupo menor.

Como dissemos logo acima, são as minorias político-culturais que, uma vez publicizando-se e enraizando-se política e culturalmente, conseguem efetivamente dinamizar uma perspectiva de desnaturalização que subjaz às instituições e aos grupos produtores de menoridade, ao fascismo-racismo-fundamentalismo. As minorias político-culturais constituem-se como sujeito, valor, prática e história que nos permite 
construir o movimento de formação e de evolução de uma dada sociedade e mesmo mais além, na exata medida em que, como fizemos ver logo acima, elas são o resto do processo de normalização dessa mesma sociedade, o bode expiatório, a negatividade que legitima esse processo de normalização e de naturalização - e, em consequência, de apoliticidade-despolitização - que caracteriza perspectivas normativas de cunho pré106 político e a-histórico próprias ao fascismo-racismo-fundamentalismo, as quais, dada essa sua condição ao mesmo tempo pré-política, a-histórica e, por isso, fortemente objetiva e missionária-messiânica, impelem a uma atitude direta de enclausuramento, de segregação, de enfrentamento e de silenciamento, seja por meio da exclusão, seja por meio da eliminação. Essa negatividade própria às minorias político-culturais, no contexto de um processo de expansão da modernidade europeia por meio da tríade eurocentrismo-racismo-fascismo e de sua correlação de racismo biológico, fundamentalismo religioso e instrumentalismo econômico, levam diretamente à colocação do fascismo como o eixo estruturante dessa produção-reprodução permanente das minorias político-culturais e, não por acaso, Aimé Césaire, em sua célebre crítica à modernidade, mostra que o nazismo não foi um acidente de percurso dessa mesma Europa, mas uma consequência direta da tríade eurocentrismocolonialismo-racismo e de sua base normativo-material, o racismo biológico, o fundamentalismo religioso e o instrumentalismo econômico, com sua imparável, incessante e globalizante tendência à imposição de uma dura e desigual modernização econômico-social a partir da relação entre centros e periferias, a partir da produção de periferias. Portanto, o nazismo não é um acidente à Europa, mas uma consequência direta de sua postura colonial, racista, fundamentalista e instrumental frente aos outros povos - o que difere entre as duas formas de fascismo é o fato de que Hitler instrumentalizou, escravizou e matou europeus (um fascismo dentro da Europa, por europeus e contra europeus), ao passo que o colonialismo foi um processo fascista contra os não-europeus, em particular, aqui, contra indígenas e negros/as - um processo etnocida-genocida-instrumentalizante muito bem tolerado pelos europeus e, em verdade, despolitizado por eles devido à afirmação do racismo. Césaire diz:

Seria preciso estudar, primeiro, como a colonização se esmera em descivilizar o colonizador, em embrutecê-lo, na verdadeira acepção da palavra, em degradá-lo, em despertá-lo para os instintos ocultos, para a cobiça, para a violência, para o ódio racial, para o relativismo moral, e mostrar que, sempre que há uma cabeça degolada e um olho esvaziado no Vietname e que em França se aceita, uma rapariguinha violada e que em França se aceita, um Malgaxe supliciado e que em França se aceita, há uma aquisição de civilização que pesa com o seu peso morto, uma regressão universal que se opera, uma gangrena que se instala, um foco de infecção que se alastra e que, no fim de todos estes tratados violados, de todas estas mentiras propaladas, de todos estes prisioneiros manietados e 'interrogados', de todos estes patriotas torturados, no fim desta arrogância racial encorajada, desta jactância ostensiva, há o veneno instilado nas veias da Europa e o progresso lento, mas seguro, do asselvajamento do continente. [...] As pessoas espantam-se, indignam-se. Dizem: 'Como é curioso! Ora! É o nazismo, isso passa!’. E aguardam, e esperam; e calam em si próprias a verdade - que é uma barbárie, mas a barbárie suprema, a que coroa, a que resume a quotidianidade das barbáries; que é o nazismo, sim, mas que, antes de serem as suas vítimas, foram os cúmplices; que o toleraram, esse mesmo nazismo, antes de o sofrer, absolveram-no, fecharam-lhe os olhos, legitimaram-no, porque até aí só se tinha aplicado a povos não europeus; que o cultivaram, são responsáveis por ele, e que ele brota, rompe, goteja, antes de submergir nas suas águas avermelhadas de todas as fissuras da civilização ocidental e cristã (Césaire, 1978, p. 17-18).

Note-se, portanto, para o que nos interessa no texto, que o núcleo central do processo sócio-institucional de produção e de reprodução de menoridades tem na correlação de eurocentrismo-colonialismo-racismo o seu núcleo fundante, imbricando, ainda como sugerem, por exemplo, Aimé Césaire (1978), Frantz Fanon (1968, 2008), Albert Memmi (1967), Achille Mbembe (2014), Eliane Potiguara (2018), Grada Kilomba (2019) e Ailton Krenak (2015), as perspectivas do racismo biológico, do fundamentalismo religioso e do instrumentalismo econômico, que levam exatamente a 
essa consolidação do fascismo sociocultural como a base da expansão colonial como e imbricada à - modernização, mas também como a consequência que se universaliza entre os sujeitos envolvidos - os primeiros deles constituídos pelos próprios colonizadores. Nesse sentido, o desbravador que "descobre" um "novo mundo" é o velho fascista disposto a tudo, a enganar e a matar tudo e todos/as, a derrubar todas as árvores e a cavar tão fundo em busca de ouro ao ponto de destruir, no dizer de Davi Kopenawa, os esteios de sustento da Terra e do Céu, levando à própria queda do céu e, assim, ao fim da vida, de toda a vida (cf.: Kopenawa e Albert, 2015, p. 64-65, p. 85-86); e esse novo mundo, o mundo dos e pelos fascistas, nada mais será do que um fascismo radicalizado, isto é, o ódio, a segregação, a desumanização e a morte normalizadas, despolitizadas. Os fascistas, então, não podem construir um mundo novo, mas piorá-lo, radicalizar e tornar mais pungente a desumanidade e a instrumentalidade que já assumem entre os seus e com eles, por meio deles. O fim último da consciência e da prática fascistas é sua própria autodestruição por meio da instrumentalização de tudo e de todos/as, ainda que antes elas destruam esses/as mesmos/as outros/as como uma necessidade moral e uma vocação existencial. Desnecessário dizer que as formas contemporâneas de colonialismo econômico, político e militar também apresentam elementos fascistas intensos, ao ponto de, munidas de uma retórica fortemente normativa ligada aos valores universalistas da civilização ocidental, mas capazes de a qualquer momento lançar mão de instrumentos de destruição em massa que garantem esses valores universalistas da civilização ocidental para si e para os/as outros/as, apertam os botões de suas armas tecnológicas para matar à distância ou constroem guetos econômicos amplos frente aos/às não-alinhados/as, condenando-os/as à inanição sem qualquer problema moral. Lá como aqui, o mundo dos fascistas é o da instrumentalidade ampla, de si e dos/as outros/as, como, aliás, estamos vendo em meio à pandemia do coronavírus, em que a manutenção do funcionamento do sistema econômico está acima da preocupação com as vidas humanas, a começar pelas "descartáveis", nesses discursos e nessas práticas fascistas, como os/as velhos/as nãoprodutivos/as - mas, "e daí? Lamento, todos vamos morrer um dia”. Enfim, a produção de menoridades, de negatividades, de restos sociais e morais é consequência da perspectiva fascista, racista e fundamentalista por trás da correlação de modernização e colonialismo e lhe serve como suporte para a autojustificação de sua normalidade e como base para a legitimação de sua prossecução universalista.

É nesse sentido que a visibilidade, a publicização e o enraizamento públicopolítico das e pelas minorias político-culturais leva exatamente à desnaturalização e ao rompimento da normalidade social e institucional, vale dizer, à politização das instituições, da sociedade, da cultura, da história, da consciência - o que permite o enquadramento, a crítica e a transformação gradativa do fascismo (mudança que exige educação, combate jurídico e deslegitimação cultural, obviamente, a partir do engajamento social, político, cultural, educacional, institucional e, por óbvio, econômico e religioso). Como produções político-normativas, as minorias na esfera pública e como sujeitos político-culturais, permitem uma dupla e imbricada forma de florescimento e de potenciação da práxis político-pedagógica, a saber: para si, no sentido de uma reafirmação e de uma reconstrução catárticas de sua integridade e de sua dignidade; para a sociedade envolvente, em termos de ativismo estético, político, do corpo-sexo-gênero visível, audível, engajado, do sujeito-grupo (o eu-nós, já que o indivíduo pertencente a uma minoria sempre será visto concomitantemente como grupo - o indivíduo negro é o negro em geral, traz à memória a negritude em geral, o fenômeno negro em geral, para o bem ou para o mal, como já afirmavam Fanon e Memmi), que somente pode sobreviver e florescer se publicizar-se e se politizar-se, isto é, se enraizar-se na esfera pública e assumir-se como sujeito político-cultural militante, e isso permanentemente. Esse passo fundamental, a superação da invisibilização, do silenciamento e do privatismo aos quais as minorias político-culturais foram empurradas pela tríade eurocentrismo-colonialismo-racismo e pelo seu baluarte, o racismo biológico, o fundamentalismo religioso e o instrumentalismo econômico, 
fundamento e dinâmica do fascismo, leva à consolidação pública, política e cultural das minorias e, aqui, ao ataque direto aos processos de normalização, de naturalização e de apoliticidade-despolitização produtores e reprodutores dessa díade maioridademenoridade. Com isso, a emergência pública, política e cultural das minorias e por elas permite um passo fundamental no que diz respeito ao combate do fascismo, a saber, a

108 crítica à lógica da identidade de cunho naturalizado e essencialista. Por meio do estudo do pensamento queer de Paul Beatriz Preciado e de Megg Rayara Gomes de Oliveira, procuraremos exemplificar e refletir sobre a ideia do sujeito trans como ficção estéticopolítica viva que desnaturaliza, des-normaliza e, assim, politiza a cultura, as práticas sociais, as instituições e os sujeitos políticos, fazendo isso por meio da própria visibilização pública da raça-sexo-gênero como descolonização e descatequização, do corpo como instrumento e prática estético-políticos, e a partir da entabulação de uma voz-práxis direta, carnal e vinculada à própria condição (o sujeito trans agindo em nome da comunidade LGBTQ+ e a partir dela, dessa sua condição e de seus anseios), de caráter político e politizante, marcada por um relato autoral, testemunhal, experiencial e mnemônico de suas experiências de marginalização, de exclusão e de violência, assim como de sua singularidade, de seus sonhos e de seus ideais, de suas alegrias e dores, ligadas, por óbvio, às descobertas e aos confrontos que, como sujeito em metamorfose, nem homem e nem mulher, ou outro/a de seu próprio corpo-gênero (segundo padrões normalizados, a-históricos), viveu no contexto de normalização, de naturalização e de apoliticidade-despolitização da díade maioridade-menoridade, no caso de Paul Beatriz Preciado em termos de sua condição de sexo-gênero sem identidade e em autocriação, no caso de Megg Rayara Gomes de Oliveira em termos de autodescoberta e autoafirmação gradativas como outra de si, ademais imbricando-se sexo, gênero e raça, e enquanto descolonização e descatequização.

\section{DA LÓGICA DA IDENTIDADE À RELACIONALIDADE E À POLITICIDADE FUNDANTES: O SUJEITO TRANS COMO DESNATURALIZAÇÃO E POLITIZAÇÃO DA CULTURA}

Antes de entrar propriamente na substituição de - e no combate a - uma lógica da identidade calcada na correlação de fascismo-colonialismo-racismoheterossexualidade compulsória, por parte das minorias político-culturais de um modo geral e dos grupos LGBTQ+ em particular, o que leva exatamente à afirmação da relacionalidade e da politicidade fundantes entre os e pelos sujeitos sociais, culturais $e$ epistêmicos - e de suas produções sociais, é importante mencionar-se que, quando acessamos a obra-práxis, a voz-práxis de um sujeito-grupo menor, encontraremos uma perspectiva autoral, experiencial, testemunhal e mnemônica autobiográfica que caracteriza de modo muito especial à manifestação estética, política e epistềmica desses mesmos sujeitos-grupos minoritários. Estamos acessando, lendo, ouvindo e interagindo com a experiência viva da marginalização, da exclusão e da violência, e não com um mero entreposto ou um sujeito-grupo representado por outro sujeito-grupo extemporâneo; o sujeito-grupo de minorias é a experiência viva do fascismo e de sua normalização-naturalização da violência e da morte por meio do racismo, da colonização, do machismo, da homofobia, da transfobia etc. E isso significa duas coisas. Uma delas que a voz-práxis, a obra-práxis do sujeito de minorias é, ao mesmo temo, uma perspectiva que correlaciona indivíduo e grupo, uma vez que, como dissemos acima, o/a negro/a, o/a "índio/a", o/a homossexual, o/a trans, a mulher etc. só o são enquanto indivíduos anormais por causa de sua pertença a uma condição coletiva, grupal anormal; o indivíduo é por causa do grupo (se pensarmos no sujeito liberal, ele possui uma esfera-dinâmica constitutiva autossubsistente em termos éticos, políticos e existenciais, o que nos permite falarmos em um sujeito que é uma entidade inserida em um grupo, mas ao mesmo tempo totalmente autônoma dele, como inclusive o reconhece Walter Benjamin relativamente ao escritor moderno ou burguês ${ }^{5}$ ). Nas minorias político-culturais, não se separa indivíduo e comunidade - daí o porquê utilizarmos o 
termo eu-nós estético-político como forma de referirmo-nos à voz-práxis do sujeito de minorias e ao seu relato da singularidade, como alteridade irredutível, e da condição de marginalização, de exclusão e de violência vivida e sofrida. Como nos diz artista plástico e escritor indígena macuxi Jaider Esbell, "De fato, minha face nunca me deixou estar imperceptível" (Esbell, 2018, p. 125). Ou, ainda: "Eu saio para ir além e a aldeia nunca sai de mim, ela se faz em outro ambiente, em tudo" (Esbell, 2018, p. 118-119). E mais, referindo-se à sua militância por meio da arte ("arte-ativismo") em torno à condição e à causa indígena no país: "A primeira observação é a identidade ou a identificação. Sou o artista de um povo, ou pertenço a um povo e sou artista” (Esbell, 2018, p. 88). A segunda delas, então, consiste exatamente nesse relato-práxis direto, carnal, vinculado, de cunho experiencial, testemunhal, mnemônico e autobiográfico em que o sujeito-grupo de minorias, uma vez publicizado, nos conta de modo nu e cru as experiências de marginalização, de exclusão e de violência vividas nesse contexto fascista-colonial-racista-heteronormativo, ao mesmo tempo em que nos apresenta sua alteridade-singularidade irredutível. É nesse sentido, aliás, que a obra-práxis e a vozpráxis do sujeito-grupo de minorias se constitui e se dinamiza como autobiografia. $\mathrm{O}$ exemplo do trabalho de Megg Rayara, acima citado, pode ilustrar bem essa inevitável e direta voz-práxis e obra-práxis que constitui a publicização de si (como indivíduogrupo, eu-nós estético-político) das e pelas minorias político-culturais. Ela nos diz:

Para fazer este trabalho, utilizei a metodologia das (auto)biografias [...], por estas se
constituírem como fragmentos que apresentam a vida com base em diversos pontos de vista
dos sujeitos. [...] o método (auto)biográfico permitiu que as (r)existências de gays
afeminados, viados e bichas pretas fossem pautadas. Quatro professores negros em
atividade em escolas públicas no Paraná e no Rio de Janeiro, que escapam às práticas da
heterossexualidade normativa, foram personagens centrais nesta pesquisa e contribuíram
decisivamente para colocar em debate os dispositivos de poder presentes no racismo e na
homofobia. Através de suas narrativas, foi possível pautar o vocabulário 'preto/a' como
categoria de análise, e não como simples adjetivo, bem como as categorias gay afeminado,
viado e bicha. [...] nenhuma categoria aqui debatida foi tratada como algo extático, fixo,
cristalizado, em uma oposição declarada às visões essencialistas que generalizam
existências desconsiderando os múltiplos processos que as envolvem (Oliveira, 2017, p. 11).

Portanto, o mais fundamental aguilhão crítico e a mais pungente práxis política das e pelas minorias se deve exatamente ao fato de que elas são o produto vivo da própria política fascista, da própria cultura colonial, racial, sexista e heteronormativa que, desde uma suposta perspectiva pré-política e a-histórica, instaura processos amplos de massificação, de unidimensionalização e, por conseguinte, de violência simbólicomaterial direta. As minorias político-culturais são produzidas-reproduzidas em termos dessa lógica da identidade de cunho pré-político, pré-cultural e a-histórico que subsume, que justifica e dinamiza a base antropológico-ontológica e epistemológicopolítica própria à normalização, no contexto do fascismo-colonialismo-racismoheteronormatividade. Sua experiência de autocompreensão, de visibilização e de resistência representa a des-hibernação ampla desse mesmo fascismo-colonialismoracismo-sexismo latente, ossificado, naturalizado enquanto prática normal (e, por isso, supostamente inexistente, não visível). E é pelo combate a essa lógica que as minorias político-culturais sobrevivem, resistem e se inserem social, política, cultural e institucionalmente como sujeito-grupo, desnaturalizando-a e politizando-a. Para começo de conversa, portanto, a compreensão, a afirmação, a construção e a vinculação pública como sujeito trans - ou como minoria político-cultural de um modo mais geral - implica em um enfrentamento direto a uma lógica da identidade relativamente à correlação de sexo, de gênero e até de raça, como vimos na passagem acima, de Megg Rayara. Na perspectiva do racismo biológico e do fundamentalismo religioso, bem como do consequente fascismo cultural, há uma correlação pré-cultural, pré-política, pré-social e a-histórica de sexo e de gênero, de modo que a cultura é dependente da - e subordinada à - biologia e a antropologia é dependente da - e subordinada à - teologia. Portanto, a estrutura genético-fisiológica configura (a) uma correlação de morfologia 
sexual e de autocompreensão de gênero, (b) uma imbricação de capacidade intelectual, raça e status social, bem como (c) o escalonamento e a metrificação recíproca de cor, etnicidade e civilização. Dourada por nuances fantásticos em termos de mistificações nacionais e religiosas, e assumindo uma morfologia dos corpos e dos gêneros de cunho dualista, definida de uma vez por todas, essa perspectiva de uma identidade dada ferreamente de modo não-político, pré-cultural e a-histórico leva ao núcleo central da imbricação fascismo-colonialismo-racismo-heteronormatividade, a saber: a justificação de uma noção forte de objetividade antropológico-ontológica e epistemológico-política que legitima uma atitude direta de enquadramento, de exclusão e, se necessário, de violência contra o sujeito-grupo dissidente, anormal, doente, não natural, moralmente decaído. Note-se o caminho básico da postura fascista-colonial-racista-heteronormativa, a saber: ele começa pela subordinação da cultura, da política e das instituições a uma ordem pré-política, pré-cultural e a-histórica considerada padrão absoluto, o único fundamento garantidor da objetividade das crenças, das práticas e dos modelos antropológicos; ele se ramifica na construção de uma noção forte de objetividade antropológico-ontológica e epistemológico-política, no duplo sentido do termo, de uma verdade que não admite contestações, porque está além da política, da história e, assim, do relativismo, e de um modelo normativo que impele tanto a uma obediência, a um enquadramento e a um controle absolutos de tudo e de todos quanto a uma perspectiva de imposição universalista-globalista de caráter missionário e messiânico, ademais ligada ao fato de que somente um ou outro líder (o fuhrer, o duce) acede a essa verdade, a conhece e pode reproduzi-la e aplicá-la socialmente (tudo isso sem qualquer moderação e sensibilidade); e chega, finalmente, na instrumentalização da vida em geral e, como fecho de abóboda, no extermínio - às vezes no extermínio em massa - de minorias político-culturais. Como nos diz Paul Beatriz Preciado relativamente à sua condição trans, esse caminho faz parte do dia a dia dos dissidentes do dualismobinarismo de gênero e de sexo, é um dos eixos centrais de sua compreensão de mundo.

\footnotetext{
$\mathrm{Na}$ intimidade do espaço doméstico, meu pai punha em marcha um silogismo que invocava a natureza e a lei moral e que acabava justificando a violência, a exclusão e inclusive a morte dos homossexuais, travestis e transexuais. Começava em geral com 'um homem tem de ser homem, e uma mulher, mulher, assim quis deus', continuava com 'o natural é a união de um homem e de uma mulher, por isso os homossexuais são estéreis e, ao final, vinha com a implacável conclusão: 'se tenho um filho viado, o mato'. E esse filho era eu (Preciado, 2019, p. 64).
}

Ora, essa condição, própria às minorias político-culturais, como resto de normalidade (lembremos: como anormalidade e anti-naturalidade que se faz pública, que se visibiliza e assume e enuncia aos quatro cantos sua voz, temos a politização, a dessacralização da vida, sua existência meramente nua e crua, efetiva politicidade, sem véu, sem fantasmagorias, ou seja, a relacionalidade no seu mais pleno sentido como eticidade), leva a que a trajetória de vida e a construção das subjetividadesintersubjetividades das e pelas minorias tenha sempre como núcleo essa experiência da negação, da exclusão e da violência cotidianas. Não se pode ser um sujeito-grupo de minorias sem, ao mesmo tempo, ser um sujeito-grupo "sujeito à violência", um sujeitogrupo para a violência (do fascista), um sujeito-grupo que emerge pela violência simbólico-material - recordar a violência, testemunhá-la, vivê-la dia após dia, nesse sentido, é o caminho vital das e pelas minorias, um dos fundamentos de sua autoconstituição e de sua autocompreensão. Não por acaso, Virginie Despentes, no prefácio ao livro de Paul Beatriz Preciado, Um Apartamento em Urano, comenta: "Tu sempre dizes que o mais estranho de converter-se em homem é conservar intacta a recordação da opressão" (Despentes, 2019, p. 11). A recordação, a experiência, o testemunho da opressão, da negação, da exclusão, da mofa ridícula, da violência vivida e sofrida como indivíduo-grupo anormal, não natural e moralmente decaído, portanto, imprime uma vigilância permanente ao sujeito-grupo de minorias, e isso no duplo sentido: ele está o tempo todo visibilizado pela cor de sua pele, pelos trejeitos de seu 
corpo, pela sua voz, pela expressão de seu amor, pela profissão de seus ritos e tradições etc., sujeito ao enquadramento do e pelo fascista; de outro lado, ele tem de se controlar para não ser violentado ainda mais por uma perspectiva social, cultural e institucional que assume o fascismo-colonialismo-racismo-heterossexualismo como princípio de normalização, de naturalização e de apoliticidade-despolitização - como princípio de violência socializadora (uma vez que, no fascista, o princípio socializador, moralizador e organizador mais básico da vida social é a violência missionária e messiânica). Nessa situação de controle e de autocontrole absolutos, do panóptico fascista que age de fora (da sociedade normalizada) para dentro de si (do resto, do esgoto da normalidade), não há momento de descanso (a não ser, com muito custo, escondendo-se dentro do armário, bem fechado, o que certamente não é fácil ou prazeroso): “[ [...] também não pude provar o gostinho de andar despreocupada por um caminho plano, em linha reta e sem obstáculos" (Oliveira, 2017, p. 23), nos conta Megg Rayara em seu fantástico $O$ Diabo em Forma de Gente: Reexistências de Gays Afeminados, Viados e Bichas Pretas na Educação. E complementa:

\begin{abstract}
Meu jeito abichalhado exigia uma vigilância constante, contribuindo para que eu controlasse meu estilo de andar e de correr, a maneira de gesticular mãos e braços e o modo como balançava a cabeça e mexia nos cabelos. Eu também tentava controlar meu jeito de falar e o tom da minha voz na expectativa de ser o menos visível (Oliveira, 2017, p. 22).
\end{abstract}

Note-se essa sensação de uma vigilância constante da sociedade e dos/as outros/as sobre ela, assim como da própria Megg Rayara sobre seus comportamentos como sujeito em descoberta, em transformação relativamente à normalizaçãonaturalização sexual, ao binarismo de gênero e à consequente heterossexualidade compulsória - o enquadramento, o controle e a violência, imbricados, não param nunca de agir nos processos de socialização-subjetivação fascistas, para os próprios fascistas e para suas vítimas, inclusive no sentido de impelir à violência salvífica e messiânica dos guardadores da norma contra o resto, o esgoto da normalidade. A lógica da identidade, isto é, a pressuposição de um fundamento pré-político, pré-cultural, pré-social e ahistórico da cultura, da antropologia, da raça-gênero-sexo, uma vez sendo naturalizada e, assim, sendo assumida como apolítica-despolitizada, torna-se eminentemente imbricada a - e geradora de uma - perspectiva de homogeneização-massificação, de enquadramento e de controle amplos (como um panóptico que agem concomitantemente no âmbito intersubjetivo e na psique individual, em vista dessa massificação-unidimensionalização) e, por fim, como fecho de abóboda, de exclusão e de assassinato planificado. Isso ocorre porque, de modo correlato, temos uma base fortemente objetiva em termos antropológico-ontológicos e epistemológico-políticos que, ao escapar a toda dúvida razoável, a um mínimo de sensibilidade moral, de abertura e de moderação paradigmáticas pode, de outro, continuar afirmando a existência e a dramaticidade do desafio e do perigo para "as maiorias" das "minorias" desvirtuadas, anormais, não naturais. O fascismo, ao assumir essa base naturalizada, pré-política e a-histórica, ao cingir-se, então, de um (e somente um) óculo da verdade tão seguro e certo que lhe motiva a matar em nome dessa mesma verdade, coloca as minorias como o fundamento de toda degenerescência social, mas, obviamente, está consciente de que, por mais que queira, não poderá eliminá-la como um todo, sem o que sua cruzada acaba e ele precisará encontrar outro inimigo, isto é, produzir outro resto ou esgoto da normalidade para justificar sua centralidade e seu protagonismo, seu domínio sobre a massa - que é, antes de tudo, um domínio por meio da legitimação e da imposição de uma ilusão ampla, irracional e instintiva, uma fake news permanente que mobiliza afetos, corpos e coletividades para a guerra mortal por meio da criação de um inimigo imaginário, síntese de todo o mal (não por acaso, no Brasil hodierno, a comunidade LGBTQ+ e os povos indígenas são essa síntese de todo o mal, que serve como base da mobilização e da prática fascista).

Em tudo isso, como dizíamos, as minorias político-culturais percebem que seu caminho de autoconstituição e de afirmação também é um caminho de resistência, de 
visibilização e de ativismo por meio de seu enraizamento na esfera pública e como sujeito político-cultural. Por outras palavras, as minorias - e, no nosso caso, o sujeitogrupo trans - aprendem que o preço da conquista de si, ou seja, a sobrevivência contra o fascismo-colonialismo-racismo-heteronormatividade e o reconhecimento público como alteridade ética e como sujeito de direitos, é a saída do armário, da cozinha, da 112 senzala, do mato e, assim, o engajamento público: pois autoconstituição e autoafirmação é - e demanda - reconhecimento comum, intersubjetivo, público, e reconhecimento exige exatamente luta social e transformação cultural e institucional, o que somente pode ocorrer pelo enfrentamento direto do fascismo-colonialismoracismo-heteronormatividade. No caso das minorias político-culturais, por conseguinte, é questão de vida e de morte a sua consolidação pública, a sua visibilidade política, a sua militância cultural e institucional, sem o que continuarão sendo mortas nos submundos a que foram relegadas e, principalmente, permanecerão condenadas ao silenciamento, à invisibilização e ao privatismo no que tange às pautas políticas e institucionais de nossa sociedade. Para florescerem - antes de tudo para sobreviverem precisam estar visíveis e atuantes na esfera pública, sua voz, seus corpos-gêneros-raças precisam estar visíveis, audíveis e cognoscíveis intersubjetivamente. Esconder-se e emudecer equivalem a respaldar - ainda que indiretamente - a sua própria negação, a sua própria aniquilação. Filhas da violência fascista, como restos da normalidade, como estigmas utilizados enquanto autojustificação do e pelo próprio fascismo, precisam desde dentro desta sociedade pulsante em termos do fascismo-colonialismo-racismoheteronormatividade, minar suas bases, princípios, práticas e sujeitos apolíticosdespolitizados e trazê-los de volta à política, à história, à relacionalidade cotidiana das lutas sociais. Como nos diz Paul Beatriz Preciado relativamente a esta politização e publicização fundamental das minorias:

\footnotetext{
Para o subalterno, falar não é simplesmente resistir à violência do performativo hegemônico. É sobretudo imaginar teatros dissidentes nos quais seja possível produzir outra força performativa. Inventar uma nova cena da enunciação, diria Rancière. Desidentificar-se para reconstruir uma subjetividade que o performativo dominante feriu (Preciado, 2018, p. 124. Cf., ainda: Krenak, 2015, p. 83-84; Werá, 2017, p. 25-29; Esbell, 2018, p. 47; Munduruku, 2018, p. 109-110; Kopenawa e Albert, 2015, p. 389-390; Fanon, 2008, p. 2829).
}

Note-se, portanto, que falar, isto é, enraizar-se, visibilizar-se e agir publicamente como sujeito político-cultural, é condição fundamental tanto para o enfrentamento da normalização e da apoliticidade-despolitização relativamente à condição e à causa das e pelas minorias quanto assumir a práxis política como lugar de transformação, de criação, de produção - sempre relacional, sempre política - de novos sujeitos, históricas, práticas, valores e símbolos. Isso não se faz na esfera privada, longe dos olhos e dos ouvidos do público e como público, mas através da afirmação da cidadania política, do dar-se a conhecer, do propor-se ao diálogo e, quando necessário, da resistência e da desobediência civis. Nesse sentido, a primeira contribuição que o sujeito-grupo trans nos traz à esfera pública e como princípio político-normativo como também o fazem as minorias político-culturais em geral - consiste exatamente na ideia, já comentada acima, de que raça, gênero e sexo não são entidades ontológicas de cunho essencialista e naturalizado; de que raça, sexo e gênero, portanto, não possuem base pré-política, pré-cultural, pré-social e a-histórica, uma vez que a própria culturasociedade-linguagem-história-política-subjetividade não tem um fundamento anterior a si, seja ele biológico, seja ele religioso. Tudo é política, tudo é político, envolvendo relacionalidade fundante, sendo totalmente normativo e estando localizado dentro - e sendo dependente de - contextos antropológicos marcados por intersubjetividade, luta, acordo, dissenso, enfim, pela e como práxis. A luta contra o fascismo-colonialismoracismo-heteronormatividade, desse modo, começa e se dinamiza sob a forma de um enfrentamento, de uma recusa e de um combate pungente, direto contra a lógica da identidade social, cultural, racial, sexual e de gênero que tem em um fundamento pré- 
político, pré-cultural e a-histórico o seu núcleo de justificação e se dinamiza, como pudemos perceber na passagem acima de Paul Beatriz Preciado, por correlatamente politizar raça, sexo e gênero, isto é, por politizar o fascismo-colonialismo-racismoheteronormatividade, e por apontar para outros mundos possíveis, e isso desde a vozpráxis das vítimas desse mesmo fascismo por si mesmas e desde si mesmas. Tudo é relacionalidade e politicidade e isso significa: é preciso desnormalizar e desnaturalizar a cultura, a sociedade, a história, as instituições, os sujeitos sociais. Como vimos acima, falar, agir, visibilizar-se publicamente é a condição de vida e de morte para as minorias político-culturais, uma vez que o fascismo-colonialismo-racismo-heteronormatividade não pode ser enfrentado por meio do esconder-se no armário, na cozinha, na senzala ou no mato, e isso significa combate à luz do dia pelo sujeito-grupo de minorias relativamente aos sujeitos-instituições-práticas fascistas. Atacar a apoliticidadedespolitização de uma identidade fascista pré-política, pré-cultural e a-histórica, assim, é o núcleo da atuação pública, política e cultural das e pelas minorias. Diz-nos mais uma vez Paul Beatriz Preciado:

\begin{abstract}
A masculinidade e a feminilidade, a heterossexualidade e a homossexualidade não são entidades ontológicas, não existem na natureza independentemente de relações sociais e redes discursivas e, portanto, não podem ser objeto de observação empírica. São o efeito de relações de poder, sistemas de signos, mapas cognitivos e regimes políticos de produção da vida e da morte. A anatomia não pode ser o fundamento sobre o qual se apoiem as agendas políticas e os juízos morais, posto que a anatomia (um sistema de representação historicamente fabricado) é em si mesma o resultado de convenções políticas e sociais cambiantes (Preciado, 2019, p. 72. Cf., ainda: Preciado, 2019, p. 176, p. 250; Oliveira, 2017, p. 60; Butler, 2003, p. 09-10, p. 23-25).
\end{abstract}

Ora, uma das consequências mais emblemáticas dessa recusa de uma base prépolítica, pré-cultural e a-histórica da cultura-sociedade-linguagem-históriaantropologia, que constitui-se como o ponto de partida do enfrentamento do fascismocolonialismo-racismo-heteronormatividade do e pelo sujeito-grupo de minorias, consiste exatamente em uma consigna que, no nosso entender, define de modo fundamental às ciências humanas e sociais contemporâneas como perspectiva antifacista e antitotalitária cujo cerne é a diversidade, a diferença, a alteridade, o/a Outro/a, o pluralismo, o multiculturalismo - perspectiva antitotalitária e antifascista que se gesta gradativamente pela emergência pública, política e cultural dessas mesmas minorias político-culturais no contexto da descolonização contemporânea, a saber: eu não gay, eu não sou trans, eu não sou índio/a, eu não sou negro/a, eu não sou mulher etc. O que isso significa? E por que essa é uma das consequências mais básicas do enfrentamento das posições essencialistas e naturalizadas relativamente à raça, ao gênero, ao sexo e ao sujeito (a)político, próprias ao fascismo? Eu não sou gay, eu não sou trans, eu não sou índio/a, eu não sou negro/a, eu não sou mulher etc., remetem para a ideia de que, contrariamente ao que assume o fascismo-colonialismo-racismoheteronormatividade, não há identidades pré-políticas, sejam elas de cunho biológico, sejam elas de cunho religioso. O/a trans, o/a gay, o/a, o/a índio/a, o/a negro, a mulher (e mesmo o homem) etc. somente podem ser compreendidos como sentido objetivo, no contexto da cultura ocidental, quando se explicita essa base pré-política e a-histórica assumida pelo fascismo-colonialismo-racismo-heteronormatividade. Por outras palavras, não existe o/a índio/a biológico/a e ontológico/a, senão que ele/a é fruto do colonialismo; não existe o/a negro/a biológico/a e ontológico/a, senão que ele/a é fruto do racismo; não existe o/a gay, o/a trans, a mulher e o homem biológicos/as e ontológicos/as, senão que eles/as são frutos do binarismo de sexo-gênero, do falocentrismo sexual-cultural e da heterossexualidade compulsória de cunho biológicoteológico. A negritude, a indianidade, a homossexualidade, a transexualidade, a feminilidade e a masculinidade etc. são construções sociais e relações políticas, são valores normativos que somente fazem sentido dentro e a partir do arcabouço histórico, político e epistêmico próprio ao fascismo-colonialismo-racismo-heteronormatividade 
ocidental e seu par maioridade-menoridade de base biológico-religiosa, essencialista e naturalizada, pré-política, pré-cultural e a-histórica, significado pelas questões da raça, do sexo, do gênero, da etnia, da civilização etc. Daí o fato de que o ativismo políticocultural dos e pelos sujeitos de minorias assume uma perspectiva de descolonização da cultura e de descatequização da mente em torno a esse eixo fascismo-colonialismo114 racismo-heteronormatividade, mostrando que as minorias somente adquirem história e sentido por causa desse eixo (e este por causa delas). Sobre o sentido de sua militância em torno à causa e à condição indígena, nos diz Ailton Krenak:

E o outro desconforto era me identificar como índio, porque índio é um erro do português, plagiando o Oswald, que disse que, quando português chegou ao Brasil, estava uma baita chuva, aí ele vestiu o índio, mas, se estivesse em um dia de sol, o índio teria vestido o português e estaria todo mundo andando pelado por aí. Isso continua valendo até hoje, e eu atualizei dizendo que o índio é um equívoco do português, não um erro, porque o português saiu para ir para a Índia. Mas ele perdeu a pista e veio bater aqui nas terras tropicais de Pindorama, viu os transeuntes da praia e acabou carimbando de índios. Aquele carimbo errado, equívoco, ficou valendo para o resto das nossas relações até hoje, e a resposta para uma pergunta tão direta e simples poderia ser tão direta e simples quanto. Quando foi que eu atinei que eu tinha que fazer essas coisas que eu ando fazendo nos últimos 50 anos da minha vida, que é quase que repetir o mesmo mantra, dizendo para esse outro "ô, cara, essa figura que você está vendo no espelho não sou eu não, é você, esse espelhinho que você está me vendendo não sou eu, isso é um equívoco"? E saí do sentimento para a prática na pista dos meus parentes mais velhos do que eu, que estavam sendo despachados da zona rural para as periferias miseráveis do Brasil, o que acontece em qualquer canto, no Norte, no Sul, em qualquer lugar (Krenak, 2015, p. 239. Cf., ainda: Munduruku, 2016, p. 20-52; Fanon, 1968, p. 25-26).

Note-se a ideia do/a índio/a como uma construção do português, que viu os/as transeuntes na praia e os carimbou de "índios/as". "Eu gostaria de lembrar", nos diz Daniel Munduruku, "que eu não sou um índio de fato, eu pertenço a um povo. Porque o índio não é absolutamente nada" (Munduruku, 2018, p. 27). Perceba-se, no mesmo diapasão, a ideia do/a negro/a como constructo (como mistificação) próprio ao eurocentrismo-colonialismo-racismo, não como uma entidade biológica definível a partir da configuração morfológica externa visível e/ou de uma análise molecular objetiva, conforme nos fala Frantz Fanon: "A civilização branca, a cultura europeia impuseram ao negro um desvio existencial. [...] aquilo que se chama alma negra é frequentemente uma construção do branco" (Fanon, 2008, p. 30). É por isso que, em consequência, Frantz Fanon afirma que há apenas um destino ao/à negro/a, e este destino é o branco: "Por mais dolorosa que possa ser esta constatação, somos obrigados a fazê-la: para o negro há apenas um destino. E ele é o branco" (Fanon, 2008, p. 28). O que ele quer dizer com isso? Que tanto a compreensão do ser negro/a quanto de sua luta anticolonial apontam para um alvo fundamental, a saber, o branco. E, nesse sentido, está em jogo exatamente a desconstrução teórico-prática da colonização, sob a forma de uma luta contra o dualismo-maniqueísmo instituído pela condição racial como base do mundo fascista-colonial. "Tenazmente", diz-nos Fanon, "questionaremos as duas metafísicas (branquitude-brancura e negritude-negrume) e veremos que elas são muito destrutivas" (Fanon, 2008, p. 26). Citamos intelectuais ligados à descolonização africana e ao pensamento indígena brasileiro, ambos dinamizados como descolonização da cultura e descatequização da mente, para mostrar que essa perspectiva de descolonização e de descatequização perpassa toda a compreensão, resistência e/como protagonismo público, político e cultural dos sujeitos-grupos de minorias, porque todos eles têm sua emergência histórica, cultural, política e epistêmica por meio do fascismocolonialismo-racismo-heteronormatividade e de seu dualismo-maniqueísmo calcado na biologia e na religião, na raça, no sexo e no gênero. Mas o mesmo pode ser dito, no caso nesse texto, em relação ao sujeito-grupo trans, porque, assim como o sujeito grupo indígena e o sujeito-grupo negro, também aquele é produzido pela correlação fascismocolonialismo-racismo-heterossexualidade compulsória, como, inclusive, pudemos ver 
nas passagens de Darwin, em que raça, sexo e gênero - e, consequentemente, também civilização, etnia e família - aparecem sempre de modo imbricado. Como diz Megg Rayara:

\begin{abstract}
A bicha nasce do discurso. Antes mesmo de adquirirmos consciência do potencial repressivo que esse termo tenta impor, ele é lançado como um torpedo que tenta um aniquilamento. Um grito que ecoa do outro lado da rua ou no pátio da escola, um desenho tosco na parede de um banheiro público, uma pregação religiosa: bicha! (Oliveira, 2017, p. 98).
\end{abstract}

O sujeito-grupo trans nasce na correlação fascismo-colonialismo-racismoheteronormatividade: essa consciência da emergência de si equivale à desnaturalização, à historicização e, então, à politização da sua condição e da sua causa e, de modo mais geral, do próprio fascismo, exigindo o passo necessário ao sujeito-grupo de minorias: a esfera pública. Exigindo outro passo necessário: a luta. Exigindo mais um passo necessário: a voz-práxis autoral, uma perspectiva estético-político-pedagógica militante das próprias vítimas por si mesmas e desde si mesmas, instituindo seu lugar de fala como aguilhão crítico e utopia política. A consequência da visibilização, do enraizamento e do engajamento público, político e cultural das minorias é a politização do fascismo, isto é, a percepção de que elas somente são por causa desse mesmo fascismo nas suas correlações com o colonialismo, o racismo e o binarismo de gênero e de sexo, bem como, por antonomásia, de que o fascismo só é e se sustenta por causa da produção e da reprodução de minorias político-culturais, da produção e da reprodução de uma cultura do medo, do estigma e da morte como seu (do fascismo) eixo estruturante. Por isso, mais uma vez, em consonância com as manifestações de Ailton Krenak, Daniel Munduruku e Frantz Fanon, vemos Paul Beatriz Preciado se pronunciar: meu corpo trans não existe (enquanto objetividade biológico-essencialista), mas apenas o binarismo de sexo-gênero, no contexto do fascismo normalizado - portanto, o corpo trans existe como sujeito-objeto político, não como dado essencialista e naturalizado de cunho pré-político e a-histórico. Ela diz:

Ao mesmo tempo que as mutações propiciadas pela administração continuada de
testosterona se fazem cada vez mais evidentes, inicio o processo legal de redesenho sexual
que me levará, se o juiz aceitar o pedido, a mudar de nome no documento nacional de
identidade. Os dois processos, o bioformológico e o político-administrativo, não são,
entretanto, convergentes. Embora o juiz avalie as mudanças físicas (apoiado em um
indispensável diagnóstico psiquiátrico) como condição da redesignação de nome e de sexo à
minha pessoa legal, estas mudanças não podem ser reduzidas de nenhum modo à
representação dominante do corpo masculino segundo a epistemologia da diferença sexual.
À medida em que me aproximo da aquisição do novo documento, dou-me conta com pavor
de que meu corpo trans não existe nem existirá frente à lei. Levando a cabo um ato de
idealismo político-científico, médicos e juízes negam a realidade de meu corpo trans para
poder seguir afirmando a verdade do regime sexual binário. Existe então a nação. Existe o
corriqueiro. Existe o arquivo. Existe o mapa. Existe o documento. Existe a família. Existe a
lei. Existe o livro. Existe o centro de treinamento. Existe a psiquiatria. Existe a fronteira.
Existe a ciência. Existe inclusive deus. Mas meu corpo trans não existe (Preciado, 2018, p.
216).

O corpo trans não existe biologicamente, pré-politicamente e, portanto, também não existe em termos normalizados - nesse contexto do fascismo-colonialismoracismo-heteronormatividade. Existe um campo amplo de normalidade e de naturalização e, portanto, existe uma noção fortemente objetiva no que tange a modelos antropológicos e seus consequentes valores sociais, práticas institucionais e símbolos culturais. O sujeito-grupo trans não está entre eles, não faz parte deles, a não ser como esse resto de normalidade, como este esgoto de normalidade para o qual, contra o qual flui toda atividade de autojustificação da perspectiva fascista-colonial-racistaheteronormativa e com a afirmação do qual ela se nutre em toda a sua pujança e vinculação social. $\mathrm{O}$ corpo trans não existe, isto é, não pode ser qualificado e descrito dentro dessa ampla esfera de normalidade, naturalização e apoliticidade-despolitização, 
a não ser como anormalidade, antinaturalidade, chaga, degeneração. E, ao não poder ser inserido dentro dessa dinâmica normalizada e normalizadora, passa a constituir-se como a incongruência, a irracionalidade e mesmo a falha interna que põe a perder a integridade, a estabilidade e o funcionamento do sistema fascista e de seus processos de massificação e de unidimensionalização em nome da ordem interna, o que implica em 116 sua totalização como instância, valor e dinâmica únicas, ausentes de contradição e de conflito interno - fascismo como estabilização absoluta por meio da despolitizaçãoapoliticidade amplas e, no caso, por meio da afirmação e da eliminação do anormal. Em uma sociedade-cultura-consciência normalizada, naturalizada e despolitizada, como é o caso da sociedade-cultura-consciência fascista, o corpo trans não existirá como normal, como legal, como moral, mas como essa irracionalidade, essa anormalidade, essa desordem a ser erradicada epistêmica e politicamente. E, no caso do binarismo de gênero, marcado pelo dualismo macho-fêmea e pela correlação de sexo (morfologia) e gênero (autocompreensão normativa), bem como da heterossexualidade compulsória (aparelho reprodutor feminino como identidade de gênero feminina, aparelho reprodutor masculino como identidade masculina, homem para a mulher, mulher para o homem, por causa da complementaridade morfológica entre tais aparelhos), mais uma vez, também não haverá lugar para o corpo trans: autocompreensão masculina em corpo feminino? Autocompreensão feminina em corpo masculino? Ou seja, tem-se o descarrilamento da estabilidade fascista enquanto simplificação do real, do plural, do complexo, da (e por causa da) diferença, caudatária da uniformização, da massificação e da totalização fortes por meio do par maior-menor, normal-anormal. Um descarrilamento, uma falha sistêmica que impele à supressão de sua causa, à eliminação do problema. $\mathrm{O}$ corpo trans continua não existindo em termos normalizados em sua existência como vida anormal, antinatural, degenerada, indefinível e, por isso, por estar visível, mas por não existir definição sistêmica para ele, torna-se objeto de deslegitimação e de irracionalidade desse mesmo sistema - necessário para manter o fascismo, mas um inimigo, uma falha, uma degeneração que precisa ser eliminada a todo custo:

\footnotetext{
Meu corpo trans não existe como variante possível e vital do humano nos livros de anatomia e nem nas representações do aparato reprodutivo sadio dos manuais de biologia da ESO. Discursos e técnicas de representação afirmam unicamente a existência de meu corpo trans como espécime em uma tecnologia do desvio que deve ser corrigida. Afirmam que existe unicamente como correlato de uma etnografia da perversão. Afirmam que meus órgãos sexuais existem apenas como déficit ou prótese. Fora do diagrama da patologia, não existe uma representação adequada de meu peito, nem de minha pele, nem de minha voz. [...] A mudança de distribuição da massa corporal e da musculatura não me faz imediatamente mais viril. Me faz tão somente mais trans, sem que essa denominação encontre uma tradução imediata em termos do binário homem-mulher. A temporalidade do meu corpo trans é o agora: não se define pelo que era antes, nem pelo que se supõe que terá de ser (Preciado, 2019, p. 217).
}

O corpo trans é presente. Passado não é, porque não existe como normalidade, como objetividade biológico-ontológica. Futuro não é, porque está em construção, em devir, embora, dentro do contexto de uma normalização fascista, ainda não se saiba para onde (pois, inclusive, pode muito bem ser destinado à morte, ao caixão, por causa da violência permanente sofrida como minoria). Somente lhe resta o tempo presente, a atualidade pura e efetiva, a carnalidade, a vinculação e a politicidade em sua plenitude. Paradoxalmente, portanto, o corpo trans - como correlação de normatividade e morfologia - existe aqui e agora e remodela aqui e agora o sentido dado a ele e ao seu lugar político, cultural, social, epistêmico, econômico, religioso, normativo etc. Ele não existe em um complexo normalizado e em um sistema objetivo naturalizado marcados pelo fascismo-colonialismo-racismo-heteronormatividade, a não ser enquanto anormalidade e chaga, como erro do sistema, como interrupção do funcionamento, como quebra da inteligibilidade e da ordem, até como inversão da inteligibilidade e da ordem da vida, da ordem antropológica do sexo-gênero. Mas ele existe para o sujeito- 
grupo de minorias, para esse sujeito-grupo como minorias que está em processo de autodescoberta e de autotransformação. Existe como problema, como contradição, como descoberta, como criação. "Tinha a incômoda sensação de que eu era a única no mundo", nos diz Megg Rayara (Oliveira, 2017, p. 163). O sujeito-grupo trans existe para si como (in)efetividade em primeiro lugar, como confronto com o que sente e com o que lhe é dado como normalizado e naturalizado; e, na medida em que se enraíza publicamente, em que se faz ver e ouvir para os/as outros/as, também passa a existir, ainda que como essa aberração, como essa anomalia, como uma questão intersubjetiva. Então o sujeito-grupo trans passa a existir e a tornar-se efetivo nessa dialética entre sistema e antissistema, entre normalidade e anormalidade, entre fascismo e politização, entre fundamentalismo e historicidade, entre morte e vida, entre ossificação e transformação. Em um caso, o sujeito-grupo trans, como quebra dessa normalidade e interrupção da inteligibilidade e da ordem sistêmicas do fascismo, é o gérmen da destruição que precisa ser aniquilado e que dá vida e sobrevida ao próprio fascismo (não por acaso o fascismo se utiliza pungentemente das minorias - e do discurso em torno a elas, sobre elas - como chaga e degeneração para justificar sua luta salvífica e sua vocação missionária e messiânica); no outro caso, o sujeito-grupo trans, como sujeito que vive para si e que se descobre não apenas vivo para si, isto é, autoconsciente, um ser de desejos, afetos e interesses, mas também para a coletividade na qual está inserido, torna-se aguilhão crítico e base normativa que, na sua busca por autodescoberta, autoconstrução e autotransformação, dá-se conta de que somente pode fazê-lo por meio do tornar-se sujeito político-cultural, por meio de uma práxis de enfrentamento do fascismo. E com essa situação de sujeito antifascista e antitotalitário, de sujeito que traz a descolonização da cultura e a descatequização da mente para o cerne da vida democrática, de seus processos culturais e de suas instituições, esse mesmo sujeito-grupo trans descobre que sua suposta negatividade é nada mais nada menos que o verdadeiro núcleo da política e a dinâmica central e estopim detonador da dialética social. Diz-nos sobre isso Paul Beatriz Preciado:

Meu corpo trans é uma instituição insurgente sem constituição. Um paradoxo
epistemológico e administrativo. Devir sem teleologia e referente, sua existência inexistente
é a destituição ao mesmo tempo da diferença sexual e da oposição
homossexual/heterossexual. Meu corpo trans se volta contra a língua daqueles que o
nomeiam para negá-lo. Meu corpo trans existe, como realidade material, como conjunto de
desejos e práticas, e sua inexistente existência põe tudo em xeque: a nação, o corriqueiro, o
arquivo, o mapa, o documento, a família, a lei, o livro, o centro de internação, a psiquiatria,
a fronteira, a ciência, deus. Meu corpo trans existe (Preciado, 2019, p. 217-218).

Essa inexistência existente do sujeito-grupo trans, no sentido de um nãoreconhecimento pela lógica fascista e de uma anormalidade incapaz de gerar inteligibilidade e de estabilizar a ordem do sistema composto pela correlação fascismocolonialismo-racismo-heteronormatividade, mas ao mesmo tempo como um sujeito vivo, como símbolo e normatividade para si e desde si mesmo, leva diretamente à política, aponta sempre para a politicidade e para a relacionalidade no que tange à construção dos sujeitos, das histórias, das práticas, dos valores e dos signos em comum. A incapacidade de ser nomeado, compreendido e justificado dentro de uma lógica sistêmica fascista, de caráter normalizado e naturalizado, apolítico-despolitizado, portanto, é o signo mais visível não apenas de sua existência, mas da aguda politização que ele gera, uma vez emperrando o funcionamento normalizado, naturalizado e apolítico-despolitizado desse mesmo sistema fascista. A vida social, portanto, com sua relacionalidade, politicidade e intersubjetividade fundantes, uma vida social que é feita por e entre sujeitos e tradições herdadas, com todas as lutas consentâneas a um contexto intersubjetivo, relacional e político, retoma seu caminho dialético, sua tensão e sua desordem cotidianas, por causa das diferenças na e como política. Ou seja, se a sociedade-cultura-consciência fascista somente sobrevive se naturalizar e normalizar modelos antropológicos, normas, práticas e símbolos em comum, ao mesmo tempo em 
que produz um sujeito-grupo-horizonte de negatividade que, como empecilho ao sistema, deve ser aniquilado e, antes de tudo, permanentemente lembrado na esfera pública, na cultura social e na consciência moral; se, portanto, a sociedade-culturaconsciência fascista tende a despolitizar as diferenças para negá-las, gerando massificação e unidimensionalização plenas, como se a sociedade fosse uma grande 118 família homogênea, sem diferenciações e de plena identidade interna, estruturada hierarquicamente e marcada por ordem e estabilidade férreas; se o fascismo somente é possível enquanto negar a política das e pelas diferenças e instituir o dualismomaniqueísmo salvífico, messiânico e missionário como seu eixo vital mais básico; se, finalmente, o sistema fascista somente pode funcionar bem ao homogeneizar, massificar e despolitizar a coletividade por meio da imposição de uma identidade plena sem diferenciações, complexidade e contradições internas, como uma fantasiosa grande família indivisa e completamente imobilista em termos de constituição, relação e evolução, então a consolidação das minorias político-culturais em termos de esfera pública e sua militância frente às instituições, aos sujeitos e à cultura em comum traz novamente a necessidade de mediações institucionais, de confrontos e de acordos sociopolíticos e de formação de consensos e instituição de valores, de práticas e de símbolos renovados capazes de dar conta da complexidade da vida social. O dualismomaniqueísmo fascista não apenas despolitiza os sujeitos, as práticas e os valores sociais, como também os simplifica sob o signo do bom e do mal, do normal e do anormal, do natural e do antinatural, do maior e do menor. Com isso, ele perde de vista a complexidade que é própria à pluralidade, que é gerada pela pluralidade, fazendo com que a alteridade não somente seja marginalizada, senão que também negada, e isso de modo tal que a política entre os diferentes sujeitos-grupos é substituída pelo poder absoluto do fuhrer, que se coloca acima da própria dúvida razoável e rompe com as mediações dialéticas das instituições em comum e dos múltiplos sujeitos sociais entre si e para si. Nesse sentido, mais uma vez, as minorias na esfera pública e como sujeitos político-culturais militantes fortalecem a política e as instituições, de modo que sua condição, agora visibilizada, se torna em aguilhão crítico da democracia, como perspectiva-práxis antifacista e antitotalitária, altamente pluralista e rompendo com a massificação social e a simplificação da realidade levadas a efeito por esse mesmo fascismo. Sobre a condição e o ativismo trans como crítica, diz-nos Paul Beatriz Preciado:

Com a decisão de construir minha subjetividade com a testosterona, como o xamã constrói a sua com a planta, assumo a negatividade de meu tempo, uma negatividade que me vejo forçado a representar, e contra a qual me vejo forçado a lutar desde essa encarnação paradoxal que é ser um homem trans no século XXI. [...] Minha in-existente existência como homem trans é ao mesmo tempo o clímax do antigo regime sexual e o princípio do seu colapso, o termo de uma progressão normativa e o começo de uma proliferação futura (Preciado, 2019, p. 27).

Note-se a afirmação, acima, de que a condição trans, uma vez na esfera pública e como questão política e institucional em comum, leva ao clímax a condição sistêmica de negatividade, isto é, de produção institucionalizada e cotidiana de menoridades, esta que é a base do fascismo. E, ao fazer isso, confronta esse mesmo fascismo, para começo de conversa desnaturalizando-o e politizando-o, por meio da própria visibilidade que ele tentou esconder e a partir do próprio ativismo que ele tentou negar através da produção-reprodução da menorização, por meio do apagamento da dissonância, da contradição, da alteridade. Com isso, temos uma reorientação, uma transformação das categorias trans, mulher, negro/a, índio/a, gay etc. Elas perdem esse seu significado como menoridade, como anormalidade, como negatividade e se tornam em positividade, isto é, passam a ser afirmadas como base normativa, aguilhão crítico e utopia antifascistas e anti-totalitárias, dando origem a uma voz-práxis efetivamente democratizante, inclusiva e participativa que parte das margens para o centro, que vai dos sujeitos-grupos de minorias para as instituições, politizando o fascismo como eixo e 
dinâmica produtora e reprodutora de violência simbólico-material, geradora de simplificação, de dualismo e de maniqueísmo sociais, cujo resultado é a morte. Para as minorias político-culturais, o corpo, o sexo, o gênero, a cor, tudo se transforma em instrumento político-normativo da crítica, da reflexividade, do enquadramento, da luta. Essa, conforme nos atestam intelectuais pertencentes a estas minorias, conforme nos atesta, inclusive, o ativismo dessas mesmas minorias, é a perspectiva descolonizadora e descatequisadora por excelência, e ela tem no enfrentamento do fascismo-colonialismoracismo-heteronormatividade seu objetivo mais pungente. Para Megg Rayara:

Ao se afirmarem como gays afeminados, viados ou bichas, os sujeitos desta pesquisa atribuem um sentido positivo aos termos que foram utilizados para agredi-los e marginalizálos. Há deliberadamente um processo de apropriação de conceitos que procura mantê-los deslocados dos centros formais de poder, impondo uma existência a partir da margem (Oliveira, 2017, p. 176).

A reformulação de que Megg Rayara e Paul Beatriz Preciado nos falam - e nós podemos percebê-la também no contexto da descolonização africana, do pensamento indígena brasileiro, no feminismo e dos próprios estudos culturais - na utilização dessa identidade como minorias para o enquadramento do próprio fascismo e, no caso, para uma luta descolonizadora contra perspectivas pré-políticas, pré-culturais e a-históricas relativamente à raça, ao sexo e ao gênero leva, como dissemos, a uma afirmação positiva da referida condição: suas alteridades e suas experiências de marginalização, de exclusão e de violência servem como paradigma, como eixo de inteligibilidade para a crítica social, bem como enquanto utopia de uma sociedade mais justa, solidária e inclusiva. As minorias usam seu lugar de fala como experiência catártica para si e como aguilhão crítico-emancipatório direcionado ao esfacelamento dessa correlação fascismo-colonialismo-racismo-heteronormatividade. De negatividade, as minorias assumem-se como lugar de fala inultrapassável para a construção de uma sociedadecultura-consciência antifascista, antitotalitária e antinormalizadora, uma sociedadecultura-consciência que, ademais, se enriquece pela pluralidade, pela alteridade, e que se complexificam com esta, exigindo mais política, mais reconhecimento, mas integração, mais participação, mais direitos humanos, mais democracia etc. Note-se, com isso, que esse lugar de fala não é a reestilização do argumento fascista de uma base pré-política, pré-cultural e a-histórica para a identidade individual e social. O lugar de fala, ao assumir a condição negra, gay, indígena, feminina, homossexual etc., não objetiva reproduzir uma interpretação biológica e ontológica da antropologia, da cultura, da política e, portanto, não objetiva nem monopolizar o discurso e a prática e nem excluir do discurso e da prática - sua lógica não é o binarismo maioridademenoridade, mas a destruição das fronteiras pré-políticas e a-históricas próprias ao e construídas e utilizadas pelo fascismo. O lugar de fala retrabalha o sentido dessas minorias e seu potencial político-normativo a partir exatamente de uma ênfase nisso que Paul Beatriz Preciado chamou a atenção acima, a saber, de sua condição presente, que pungencia o sentido relacional, carnal, vinculado, político e politizante do sujeitogrupo de minorias. A identidade advogada por esse sujeito-grupo, portanto, não é fascista e nem prega a submissão da cultura, da política e da história à biologia, ao fundamentalismo religioso e a uma noção essencialista de etnia, mas sim enfatiza e assume como eixo estruturante e dinamizador de si e da sociedade a práxis, a dialética da pluralidade, seus conflitos - em suma, a relacionalidade e a politicidade fundantes, os sujeitos-grupos políticos. Por isso mesmo, Paul Beatriz Preciado fala da condição trans como "ficção estético-política viva" (Preciado, 2019, p. 215), porque não existe um sujeito pré-político e a-histórico trans; no mesmo diapasão, ele fala das minorias na esfera pública e enquanto militância direta como um "parlamento dos corpos" (Preciado, 2019, p. 261), porque sua visibilidade é sua arma política, sua publicização é politização direta do fascismo-colonialismo-racismo-heterossexualidade compulsória seu corpo, seu sexo, seu gênero e sua raça é político, porque não existem biologicamente, mas apenas política e relacionalmente; e, como consequência, a 
política se torna "um texto ficcional" escrito sobre os próprios corpos dessas minorias: "A política é um texto ficcional na qual o livro é nosso próprio corpo. A política é um texto ficcional, com a única exceção de que é escrito tanto com sangue quanto com tinta, coletivamente" (Preciado, 2019, p. 266). Ficção estético-política viva: ficção porque não existe de modo essencial, biológico, ontológico, como algo pré-político,

120 mas sim relacional e político-politizante, como construção intersubjetiva e, no caso, a partir do confronto e do combate sem tréguas ao fascismo-colonialismo-racismoheterossexualidade compulsória. Ficção estético-política: porque, enquanto construção, o corpo-sexo-gênero-raça assume performances, adornos, trejeitos, atitudes para si e para os/as outros/as, consigo e/porque com os/as outros/as - não se trata de um condicionamento genético, mas de uma práxis crítico-criativa que se constitui e se dinamiza pela invenção, pela reinvenção e pela imaginação estético-política, e sob a forma de luta. Corpo como ficção estético-política viva porque, sem nenhuma base essencialista e naturalizada, só resta o corpo próprio, o grupo próprio, isto é, a própria vida como práxis criativa em termos estéticos, epistêmicos e políticos, a própria vida como resistência estético-epistêmico-pedagógico-política. Corpo como lugar de descolonização e descatequização, corpo como sujeito-plataforma de criação e de recriação, corpo como lugar da crítica e da utopia, corpo como lugar da educação. Corpo-grupo - lembremos que o sujeito e o grupo de minorias não se separam, estão imbricados - como normatividade no mais alto sentido do termo: por isso, inclusive, a política como parlamento dos corpos, como texto escrito no corpo do sujeito-grupo, que milita como corpo, pelo corpo, a partir dele, sempre contra o fascismo-colonialismoracismo-heteronormatividade.

\section{CONSIDERAÇÕES FINAIS}

No texto, procuramos tematizar o pensamento trans-queer de Paul Beatriz Preciado e de Megg Rayara Gomes de Oliveira com o intuito de analisar a constituição e a veiculação pública, política e cultural da voz-práxis estético-político-epistêmica do e pelo sujeito-grupo de minorias relativamente à sua condição e à sua causa e, como consequência, ao seu posicionamento antifacista e antitotalitário que tem por objetivo o enfrentamento e a desconstrução da correlação fascismo-colonialismo-racismoheterossexualidade compulsória a partir da desnaturalização e, portanto, da politização de seus (do fascismo) supostos fundamentos pré-políticos, pré-culturais e a-históricos. Ao fazermos isso, procuramos explicitar que a voz-práxis trans parte da quebra da lógica da identidade fascista, que subordina a cultura, a história, o social, a linguagem e a política à biologia e, de modo mais geral, à ontoteologia, de modo não apenas a despolitizar os sujeitos, as instituições, as relações, as práticas, os valores e os signos socialmente vinculantes, mas também a se produzir concomitantemente uma ordem sistêmica altamente massificada, unidimensional e totalitária e um grupo-sujeito menorizado, decaído que, por seu caráter antinatural e anormal, mobiliza as paixões, os afetos, a ação e o apoio de grupos e de subjetividades normalizados em torno ao próprio fascismo, servindo-lhe de sustento e de legitimação. Por outras palavras, ao atacar a lógica da identidade fascista, as minorias político-culturais de um modo geral e o a vozpráxis estético-político-pedagógica trans em particular apontam para o fato de que o fascismo somente consegue proeminência social por meio da construção de minorias normativamente decaídas que, como anormalidade e antinaturalidade, são utilizadas como legitimação de uma ordem apolítica-despolitizada e ferreamente homogênea calcada na estigmatização e na morte, ordem essa concebida como uma grande família indivisa e de forte identidade interna que encontra seu sentido na opressão direta dessas mesmas minorias como mal absoluto, como o grande bicho papão que nos coloca em obediência cega e instiga nossos instintos de medo e de morte contra esse mal absoluto sob a forma de um corpo-sujeito-grupo degenerado que ameaça nossa vida-famíliapátria bem-aventurada. 
Da crítica à lógica da identidade, pudemos aprender, com o pensamento transqueer em diálogo com a descolonização africana, o pensamento indígena brasileiro e o feminismo, que a construção e a autoconstrução de sujeitos sociais é basicamente dinamizada a partir de uma perspectiva-práxis relacional, política-politizante e intersubjetiva, de modo que a "identidade" desses sujeitos não é caudatária nem da biologia (morfologia, físiologia, genética) e nem de uma base religiosofundamentalista, ambas supostamente anteriores à política, à relação, ao conflito, aos dissensos e aos acordos. As identidades sociais não são estanques e nem ossificadas no tempo e no espaço políticos-culturais-históricos, senão que são construções decorrentes das interações, dos conflitos, das intersecções, dos acordos e das simbioses recíprocas. Por isso, as consignas de "não somos negros/as", "não somos índios/as", "não somos gays", não somos trans", "não somos mulheres", ou seja, não somos biologia, perspectiva essencialista e naturalizada, mas cultura, linguagem, política e, nisso, alteridades singulares em relação, a partir da relação, como relação. Dessa superação da lógica da identidade que leva à afirmação da relacionalidade, da politicidade e da intersubjetividade fundantes no que se refere à construção dos e entre os sujeitos, pelos sujeitos, chegamos, no caso das minorias político-culturais, a uma perspectiva de descolonização da cultura e de descatequização da mente que parte do sujeito-grupo de minorias como alteridade-singularidade radical e como produção político-normativa no contexto do fascismo-colonialismo-racismo-heterossexualidade compulsória e que traz à esfera pública sujeitos político-culturais marginais, marginalizados, os quais, ao visibilizarem seus corpos, suas cores, seus trejeitos, suas linguagens, suas histórias, suas práticas e seus símbolos, bem como as próprias situações de marginalização, de exclusão e de violência vividas e sofridas, possibilitam uma politização direta do fascismo-colonialismo-racismo-heterossexualidade compulsória, abrindo espaço para o pluralismo, a contradição, a complexidade, a diferenciação, e colocando a política como a práxis de resolução dos desafios dali advindos, levando à solidificação das instituições democráticas como a arena e o lugar de mediação social em nome dos direitos, da inclusão, do reconhecimento e da participação amplos, universais (estas instituições também assumindo, em consequência, um caráter antifascista e antitotalitário). Rompe-se, assim, com a massificação, a unidimensionalização e o totalitarismo fascistas e instaura-se uma perspectiva política e politizante radicalizada, que desnaturaliza tudo e todos e que vai das margens da sociedade civil para as instituições e vice-versa, em um movimento permanente.

Nesse sentido, chegamos ao lugar de fala das e pelas minorias político-culturais, à consolidação de sua voz-práxis publicizada que, ao romper com o silenciamento, a invisibilização e ao privatismo aos quais foi empurrada, enraíza-se profunda e definitivamente na cultura, na política e nas instituições cotidianas, instaurando, como dissemos acima, uma postura antifascista e antitotalitária que serve como barreira de contenção e valor pedagógico de combate ao fascismo e em nome da pluralidade, dos direitos humanos, da democracia, da inclusão, da participação e do reconhecimento ampliados. Esse lugar de fala, como também dissemos acima, parte da afirmação dessas identidades políticas e tem por meta sua promoção como singularidade, mas também sua utilização como substrato normativo da crítica social, da reflexividade política, do reconhecimento cultural e mesmo de uma utopia normativa que leva à democracia, que exige mais democracia em todos os âmbitos da sociedade, da cultura para a política, da política para o direito, do direito para a educação, da educação para a economia, da economia para os regimes epistemológicos, destes para as artes etc. Na voz-práxis das minorias político-culturais e por elas mesmas, desde si mesmas, por conseguinte, nós encontramos sujeitos, histórias, práticas, valores e símbolos que foram produzidos em termos da correlação fascismo-colonialismo-racismo-heterossexualidade compulsória e que têm condições plenas e efetivas de desmilitarizar a cultura e a consciência fascistas, bem como de fornecer uma base normativa, política e pedagógica civilizadora e humanizadora para nós e para nossas gerações futuras. Como dissemos acima, trata-se de um baluarte crítico-criativo que permite o sustento e a maturação da utopia 
democrática como perspectiva antitotalitária e antifascista de caráter igualitário, inclusivo e participativo entre todos/as, por todos/as, para todos/as, sem recorrer-se mais à necessidade fascista de produção-reprodução de menoridades para a autojustificação e a estabilidade sociais, ou seja, uma democracia que elimina a cultura do medo, do estigma e da morte e que assume a alteridade, os direitos humanos e a 122 justiça como seus valores mais fundamentais.

\section{REFERÊNCIAS}

ARENDT, Hannah. Origens do totalitarismo. São Paulo: Companhia das Letras, 1989.

BENJAMIN, Walter. Magia e técnica, arte e política. São Paulo: Brasiliense, 1987.

BUTLER, Judith. Problemas de gênero: feminismo e subversão da identidade. Rio de Janeiro: Record, 2003.

CÉSAIRE, Aimé. Discurso sobre o colonialismo. Prefácio de Mário de Andrade. Lisboa: Livraria Sá da Costa Editora, 1978.

DARWIN, Charles. A origem do homem e a evolução social. São Paulo: Hemus, 1974.

DAVIES, Angela. Mujeres, raza y clase. Madrid: Ediciones Akal, 2004.

DESPENTES, Virginie. "Prólogo", p. 09-15. In: PRECIADO, Paul Beatriz. Un apartamento en urano. Barcelona: Editorial Anagrama, 2019.

DUSSEL, Enrique. 1492, o encobrimento do outro: a origem do mito da modernidade. Petrópolis: Vozes, 1993.

ESBELL, Jaider. Jaider Esbell. Organização de Kaká Werá. Coordenação editorial de Sergio Cohn e de Idjahure Kadiwel. Rio de Janeiro: Azougue Editorial, 2018 (Coleção Tembetá).

FANON, Frantz. Os condenados da terra. Prefácio de Jean-Paul Sartre. Rio de Janeiro: Paz e Terra, 1968.

FANON, Frantz. Pele negra, máscaras brancas. Salvador: Editora da UFBA, 2008.

HABERMAS, Jürgen. Teoria do agir comunicativo: racionalidade da ação e racionalização social. São Paulo: Martins Fontes, 2012.

HONNETH, Axel. Luta por reconhecimento: a gramática moral dos conflitos sociais. São Paulo: Editora 34, 2003.

hooks, bell. Olhares negros, raça e representação. São Paulo: Elefante, 2019.

KILOMBA, Grada. Memórias da plantação: episódios de racismo cotidiano. Rio de Janeiro: Cobogó, 2019.

KOPENAWA, Davi; ALBERT, Bruce. A queda do céu: palavras de um xamã yanomami. São Paulo: Companhia das Letras, 2015.

KRENAK, Ailton. Encontros. Rio de Janeiro: Azougue Editorial, 2015.

MBEMBE, Achille. Crítica da razão negra. Lisboa: Antígona, 2014.

MEMMI, Albert. Retrato do colonizado precedido pelo retrato do colonizador. Rio de Janeiro: Civilização Brasileira, 1967.

MUNDURUKU, Daniel. Memórias de índio: uma quase autobiografia. Porto Alegre: EDELBRA, 2016.

MUNDURUKU, Daniel. Daniel Munduruku. Organização de Sérgio Cohn e Idjahure Kadiwel. Rio de Janeiro: Azougue Editorial, 2018.

OLIVEIRA, Megg Rayara Gomes de. O diabo em forma de gente: (r)existências de gays afeminados, viados e bichas pretas na educação. Tese de Doutorado em Educação. Curitiba: UFPR, 2017, 192 p.

POTIGUARA, Eliane. Metade cara, metade máscara. Lorena: DM Projetos Especiais, 2018.

PRECIADO, Paul Beatriz. Un apartamento en urano. Prólogo de Virginie Despentes. Barcelona: Editorial Anagrama, 2019.

QUIJANO, Aníbal. "Colonialidad y modernidad/racionalidade", Perú Indígena, vol. 13, nº 29, p. 11-20, 1992.

QUIJANO, Aníbal. "Colonialidade do poder, eurocentrismo e América Latina”, p. 117-142. In: CLACSO. A colonialidade do saber: eurocentrismo e ciências sociais - perspectivas latino-americanas. Buenos Aires: CLACSO, 2005.

RIBEIRO, Djamila. Lugar de fala. São Paulo: Pólen Livros, 2019.

RIBEIRO, Djamila. Quem tem medo do feminismo negro? São Paulo: Companhia das Letras, 2018.

WEBER, Max. Ensayos sobre sociología de la religión (T. I). Madrid: Taurus, 1984.

WERÁ, Kaká. Kaká Werá. Organização editorial de Kaká Werá. Coordenação de Sergio Cohn e de Idjahure Kadiwel. Rio de Janeiro: Azougue Editorial, 2017.

\section{Notas}


1 Diz-nos Max Weber em termos de ponto de partida de sua ideia de singularidade da Europa moderna enquanto universalismo historicizado por meio da racionalização cultura: "O filho da moderna civilização ocidental, que trata de problemas histórico-universais, o faz de modo inevitável e lógico a partir da seguinte dinâmica: que encadeamento de circunstâncias possibilitou que aparecessem no Ocidente, e somente no Ocidente, fenômenos culturais (pelo menos como os representamos a nós) que apresentam uma direção evolutiva de alcance e de validade universais?" (Weber, 1984, p. 11; os destaques são nossos). Diz-nos Habermas relativamente ao seu ponto de partida para a autojustificação da modernidade como universalismo-globalismo pós-metafísico via racionalidade cultural-comunicativa: À medida que procuramos aclarar o conceito de racionalidade com base no uso da expressão 'racional', tivemos de nos apoiar sobre uma pré-compreensão que se encontra ancorada em posicionamentos modernos da consciência. Até o momento, partimos do pressuposto ingênuo de que na compreensão de mundo moderna expressam-se certas estruturas da consciência que pertencem a um mundo da vida racionalizado e por princípio possibilitam uma condução racional da vida. Implicitamente, relacionamos à nossa compreensão de mundo ocidental uma pretensão de universalidade. Para entender o significado dessa pretensão de universalidade, recomenda-se fazer uma comparação com a compreensão de mundo mítica. Em sociedades arcaicas, os mitos cumprem de maneira exemplar a função unificadora própria às imagens de mundo. Ao mesmo tempo, no âmbito das tradições culturais a que temos acesso, eles proporcionam o maior contraste em relação à compreensão de mundo dominante em sociedades modernas. Imagens de mundo míticas estão muito longe de nos possibilitar orientações racionais para a ação, no sentido que as entendemos. No que diz respeito às condições da condução racional da vida no sentido anteriormente apontado, constituem até mesmo uma contraposição à compreensão de mundo moderna. Portanto, na face do pensamento mítico não teriam de se fazer visíveis os pressupostos do pensamento moderno tematizados até o momento (Habermas, 2012, p. 94-95).

2 Diz-nos Darwin sobre a prática generalizada do infanticídio entre povos da América do Sul, que consideram, segundo ele leu ou ouviu dizer de outros naturalistas, que é mais fácil matar crianças que cuidá-las: "Esta prática é ainda muito difundida em nossos dias e há motivo de se crer que o fosse muito mais em tempos passados. Os povos bárbaros acham difícil manter a si mesmos e a prole, e acham muito mais simples matar as crianças. Algumas tribos da América do Sul, segundo Azara, eliminaram tantas crianças de ambos os sexos que estiveram a pique se se extinguir. Parece que as mulheres das ilhas da Polinésia matam de quatro a cinco e até dez de seus filhos; Ellis não conseguiu encontrar uma que não tivesse matado pelo menos um" (Darwin, 1974, p. 681). Note-se a similitude entre esta posição e a posição de Habermas (que ele retira da antropologia da segunda metade do século XIX e da primeira metade do século XX) relativamente as culturas nãomodernas: "[...] imagens de mundo míticas impedem um desacoplamento categorial entre natureza e cultura, e isso não apenas no sentido de um emaranhamento conceitual de mundo social e mundo objetivo, mas também no sentido de uma reificação da imagem de mundo linguística, o que tem por consequência que a imagem de mundo seja preenchida dogmaticamente com determinados conteúdos privados de um posicionamento racional e, com isso, privados de crítica" (Habermas, 2012, p. 106).

3 Novamente na posição de Habermas: o sujeito não-moderno não consegue compreender-se e nem compreender a história mais ampla da evolução do gênero humano, da unidade última do gênero humano, uma vez que sua mentalidade é arcaica, isto é, sujeito do passado. Somente o sujeito moderno, que é o sujeito do presente e aberto ao futuro, pode fazê-lo tanto em relação a ele, o sujeito moderno, quanto em relação ao outro, o sujeito arcaico - inclusive imbricando-os no grande gênero humano cujo ápice é o sujeito moderno, por outras palavras: definido pelo sujeito moderno. Habermas diz: "Segundo a 'perspectiva do pensamento ilustrado', o pensamento selvagem gera uma 'dupla ilusão': (1) uma ilusão sobre si mesmo: à identidade por ele criada uma existência exterior ao ser humano e independente dele, alienando-o de si mesmo em suas próprias imagens de mundo; (2) o pensamento percebe o mundo como possuindo seres imaginários análogos 
ao ser humano" (Habermas, 2012, p. 101).

4 Diz Darwin: "No gênero humano, especialmente entre os selvagens, muitas são as causas que interferem na ação da seleção sexual, no que diz respeito ao aspecto físico. Os homens civilizados sentem atração pelas qualidades mentais das mulheres, pela riqueza e, sobretudo, pela posição social; efetivamente, é raro que o homem se case com uma mulher de condição social muito inferior à sua. Os homens que se casam com as mulheres mais atraentes nem por isso terão possibilidades maiores de procriar uma longa linha de descendentes do que as têm aqueles que desposam mulheres de aspecto mais comum, com exceção daqueles que herdam sua fortuna por primogenitura. No que diz respeito à forma de seleção oposta, isto é, daquelas em que são as mulheres que selecionam os homens mais atraentes, embora aconteça que nas nações civilizadas elas possam escolher livremente ou quase livremente - o que não se dá entre os povos bárbaros -, a sua escolha é notavelmente influenciada pela posição social e pelos recursos econômicos do homem; além disso, o êxito na vida deste último depende muito das suas energias e capacidades intelectuais, ou do fruto destas mesmas capacidades nos antepassados" (Darwin, 1974, p. 674-675).

5 "Podemos fazer uma travessia marítima e cruzar o oceano, sem terra à vista, vendo unicamente o céu e o mar. É o que faz o romancista. Ele é o mudo, o solitário. [...] O romancista se separou do povo e do que ele faz. A matriz do romance é o indivíduo em sua solidão, o homem que não pode mais falar exemplarmente sobre suas preocupações, a quem ninguém pode dar conselhos, e que não sabe dar conselhos a ninguém. Escrever um romance significa descrever a existência humana, levando o incomensurável ao paroxismo" (Benjamin, 1987, p. 59). 